UMETNOSTNOZGODOVINSKI INŠTITUT FRANCETA STELETA ZRC SAZU

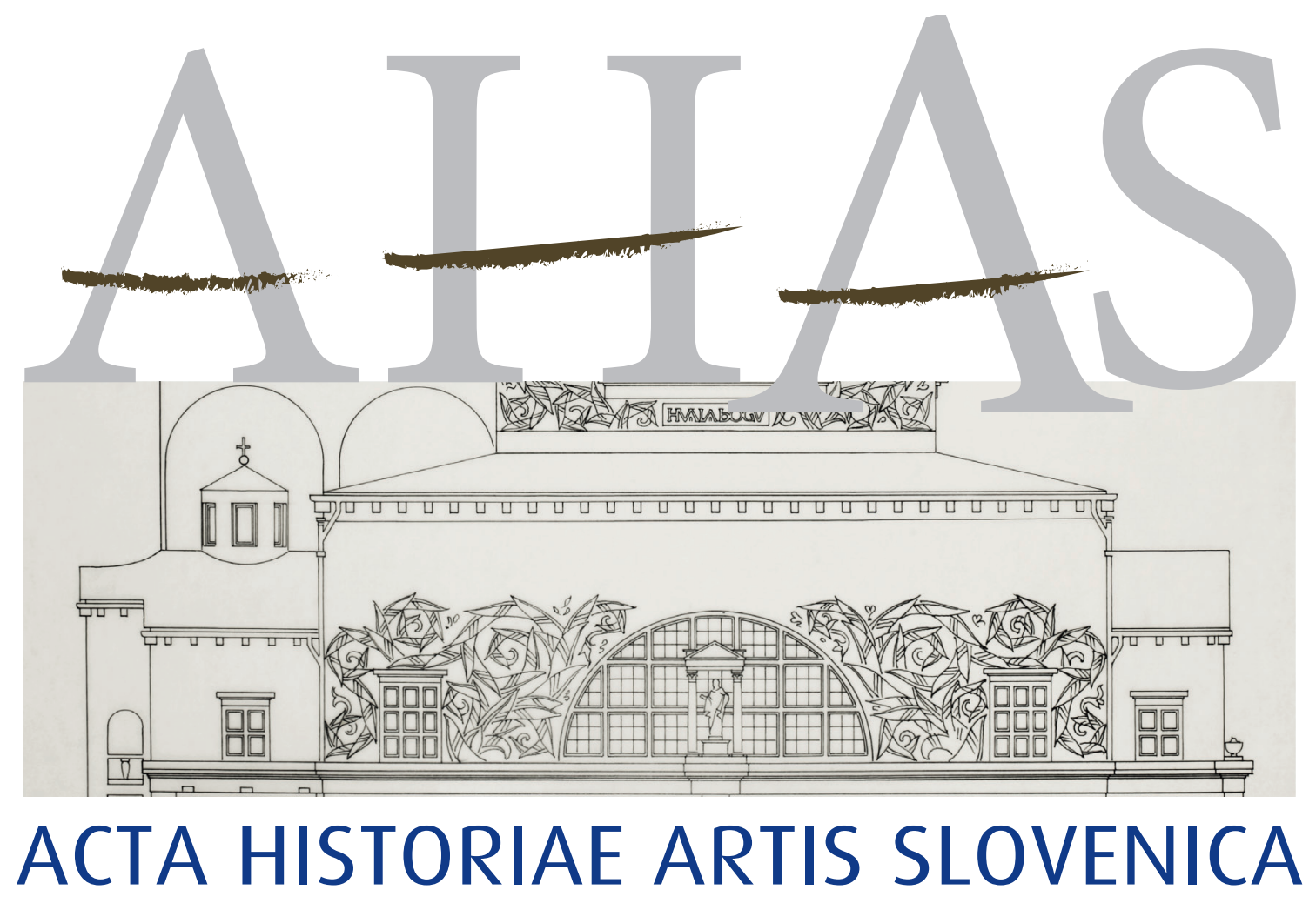

$26 \mid 1 \cdot 2021$ 
Umetnostnozgodovinski inštitut Franceta Steleta ZRC SAZU

France Stele Institute of Art History ZRC SAZU

\section{ACTA HISTORIAE ARTIS SLOVENICA \\ $26 \mid 1 \cdot 2021$}


Acta historiae artis Slovenica, 26/1, 2021

Znanstvena revija za umetnostno zgodovino / Scholarly Journal for Art History

ISSN 1408-0419 (tiskana izdaja / print edition) ISSN 2536-4200 (spletna izdaja / web edition)

Izdajatelj / Issued by

ZRC SAZU, Umetnostnozgodovinski inštitut Franceta Steleta / ZRC SAZU, France Stele Institute of Art History

Založnik / Publisher

Založba ZRC

Glavna urednica / Editor-in-chief

Katarina Mohar

Uredniški odbor / Editorial board

Renata Komić Marn, Tina Košak, Katarina Mohar, Mija Oter Gorenčič, Blaž Resman, Helena Seražin

Mednarodni svetovalni odbor / International advisory board

Günter Brucher (Salzburg), Ana María Fernández García (Oviedo), Hellmut Lorenz (Wien),

Milan Pelc (Zagreb), Sergio Tavano (Gorizia-Trieste), Barbara Wisch (New York)

Lektoriranje / Language editing

Oliver Currie, Manuela Dajnko, Andrea Leskovec, Tjaša Plut, Sergio Sozi

Prevodi / Translations

Ervin Köstler, Martina Malešič, Nika Vaupotič, Alessandro Quinzi, Samo Štefanac, Polona Vidmar

Celostni strokovni in jezikovni pregled / Expert and language editing

Blaž Resman

Oblikovna zasnova in prelom / Design and layout

Andrej Furlan

Naslov uredništva / Editorial office address

Acta historiae artis Slovenica

Novi trg 2, p. p. 306, SI -1001 Ljubljana, Slovenija

ahas@zrc-sazu.si; https://ojs.zrc-sazu.si/ahas

Revija je indeksirana $v$ / Journal is indexed in

Scopus, ERIH PLUS, EBSCO Publishing, IBZ, BHA

Letna naročnina / Annual subscription: $35 €$; Posamezna enojna številka / Single issue: $25 €$

Letna naročnina za študente in dijake: $25 €$

Letna naročnina za tujino in ustanove / Annual subscription outside Slovenia, institutions: $48 €$

Naročila sprejema / For orders contact

Založba ZRC

Novi trg 2, p. p. 306, SI-1001, Slovenija

E-pošta / E-mail: zalozba@zrc-sazu.si

AHAS izhaja s podporo Javne agencije za raziskovalno dejavnost Republike Slovenije.

AHAS is published with the support of the Slovenian Research Agency.

Tisk / Printed by Present d. 0. 0., Ljubljana

Naklada / Print run: 400

(c) 2021, avtorji in ZRC SAZU / 2021, Authors and ZRC SAZU

Besedilo tega dela je na voljo pod pogoji slovenske licence Creative Commons 4.0 CC BY NC ND, ki pa ne velja za slikovno gradivo. Za kakršnokoli nadaljnjo rabo slikovnega gradiva je treba pridobiti dovoljenje imetnika avtorskih pravic, navedenega v poglavju Viri ilustracij. Za avtorske pravice reprodukcij odgovarjajo avtorji objavljenih prispevkov. / The text of this publication is available under the conditions of the Slovenian licence Creative Commons 4.0 CC BY NC ND, which is not valid for the published images. Any further use of images requires permission from the copyright holder, stated in the section Photographic Credits. The copyrights for reproductions are the responsibility of the authors of published papers. 


\section{VSEBINA \\ Contents}

\section{DISSERTATIONES}

Janez Balažic

Fragmentarno ohranjene gotske stenske poslikave na zahodnem panonskem robu 7

Fragmentarily Preserved Gothic Murals on the Western Edge of Pannonia

\section{Mija Oter Gorenčič}

Die monastischen und kunsthistorischen Beziehungen zwischen Gaming und den

Kartausen im heutigen Slowenien unter besonderer Berücksichtigung der Memoria und der Herrschaftsrepräsentation der Habsburger und der Grafen von Cilli

Redovne in umetnostne povezave med Gamingom in kartuzijami v današnji Sloveniji

s posebnim ozirom na memorio in likovno reprezentacijo Habsburžanov in grofov Celjskih. 50

Samo Štefanac

Ponovno o koprski Pietà

Alessandro Quinzi

Rodbinske ambicije Sigismunda grofa Attems Petzenstein v luči umetnostnih naročil

Le ambizioni familiari del conte Sigismondo Attems Petzenstein alla luce

delle committenze artistiche

Polona Vidmar

Vorfahr oder König? Zur Rezeption der Porträts des 17. Jahrhunderts unter Franz Josef Fürst Dietrichstein (1767-1854)

Prednik ali kralj? Recepcija portretov iz 17. stoletja

$v$ času Franca Jožefa kneza Dietrichsteina (1767-1854)

Mateja Maučec

Vizualna propaganda Stadlerjevih ekumenskih prizadevanj v freskah Ivane Kobilce.

Visual Propaganda of Stadler's Ecumenic Project in Frescoes by Ivana Kobilca 
Vaidas Petrulis

Kaunas - a Baltic Garden City?

Kaunas - baltsko vrtno mesto?

Damjan Prelovšek

Plečnikovi načrti za cerkev sv. Križa v Zagrebu.

Plečnik's Plans for the Church of the Holy Cross in Zagreb

Martina Malešič

Risbe iz stockholmskih arhivov. Poskus rekonstrukcije švedske izkušnje

arhitektov Franceta in Marte Ivanšek

Drawings from the Stockholm Archives. An Attempt to Reconstruct

the Swedish Experience of Architects France and Marta Ivanšek.

183

\section{APPARATUS}

Izvlečki in ključne besede/Abstracts and Keywords

Sodelavci/Contributors

Viri ilustracij / Photographic Credits

195 
DISSERTATIONES

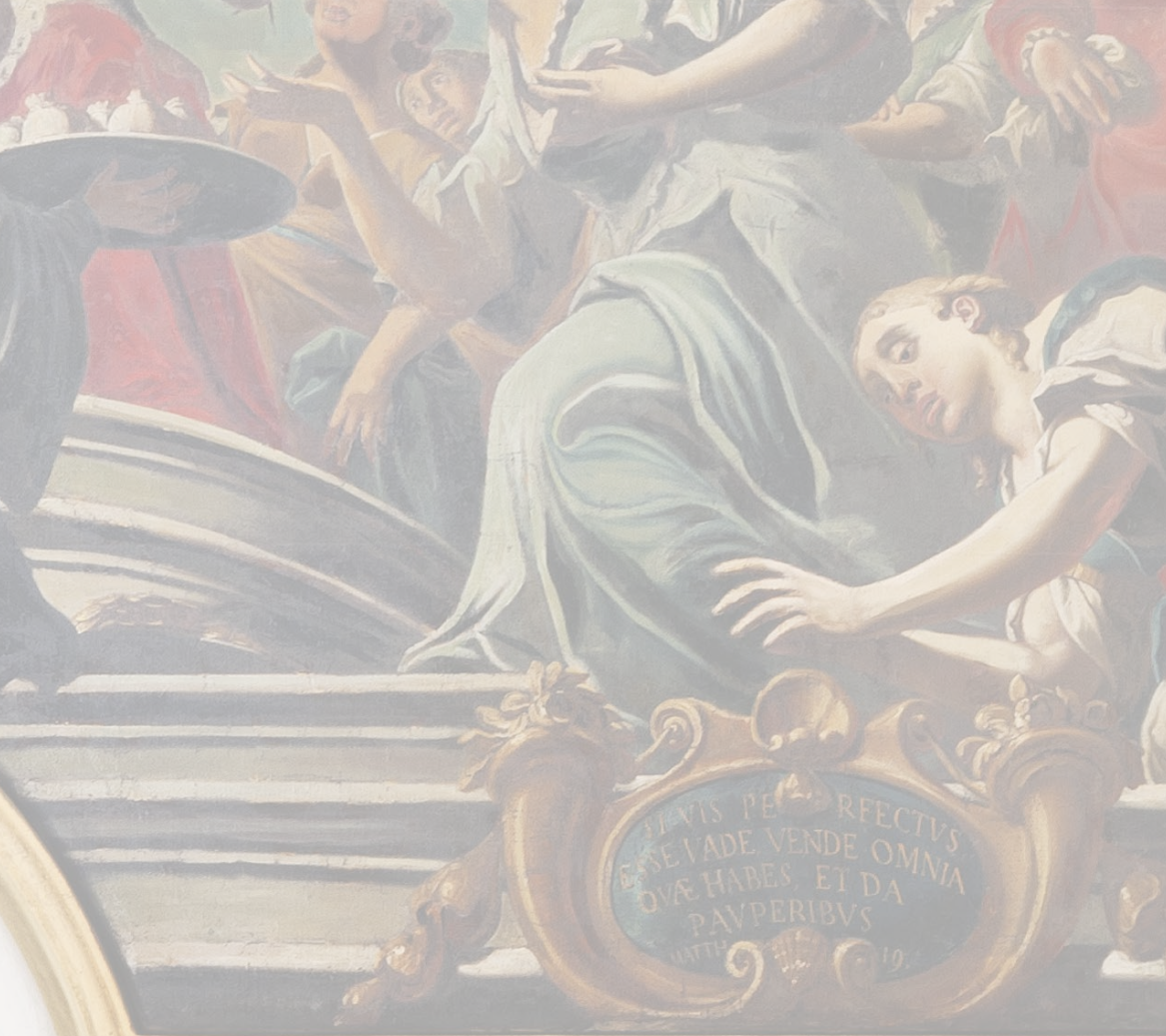




\title{
Vizualna propaganda Stadlerjevih ekumenskih prizadevanj v freskah Ivane Kobilce
}

\author{
Mateja Maučec
}

Ivana Kobilca (1861-1926) je v svojem ustvarjalnem obdobju dalj časa preživela v tujini. ${ }^{1}$ Zgodnjim začetkom na Dunaju (1879-1880?)² so sledila študijska leta v Münchnu (1881-1889), kjer se je umetnica likovno formirala in začela svojo razstavljalsko pot. V razstavnih dosežkih je Ivana Kobilca dosegla vrh leta 1891 z uvrstitvijo dveh slik, Poletja in Likaric, na pariški Salon (Salon du Champ de Mars), ki ga je organizirala Société Nationale des Beaux-Arts. Po tem dosežku se je slikarka preselila v Pariz (1891-1893), od koder se je dve leti pozneje vrnila v domovino. Od tod je leta 1897 odpotovala v Sarajevo, kjer je ostala osem let. ${ }^{3}$

V razgibanem sarajevskem obdobju je Ivana Kobilca hitro vzpostavila mrežo stikov in pridobila pomembna slikarska naročila. ${ }^{4}$ Slikarkin opus iz tega obdobja vključuje poleg večjega števila portretov, tihožitij in žanrskih orientalskih motivov tudi sakralna dela, umetnica pa je sodelovala tudi pri ilustracijah zvezka enciklopedične zbirke Die österreichisch-ungarische Monarchie in Wort und Bild o Bosni in Hercegovini (1901), prispevala reprodukcije svojih del v revijo Nada in po naročilu ljubljanskega župana Ivana Hribarja (1851-1941) naslikala večje alegorično delo za ljubljansko mestno hišo, Slovenija se klanja Ljubljani. ${ }^{5}$ Motivno razgibano obdobje je Kobilca zaključila leta 1905, ko

1 Umetnica je v tujini bivala v obdobjih 1879-1880 (Dunaj), 1881-1889 (München), 1891-1893 (Pariz), 1897-1905 (Sarajevo) in 1907-1914 (Berlin).

2 Beti ŽEROVC, Ivana Kobilca - a Career in the Context of Nineteenth-Century Women's Painting, Biuletyn historii sztuki, 76/3, 2014, str. 511, postavlja čas slikarkinega bivanja na Dunaju pod vprašaj in dopušča kot mogoče leto odhoda na Dunaj 1880.

3 Za življenjepis Ivane Kobilce gl. Stanko VURNIK, Ivana Kobilca. Spomini, Zbornik za umetnostno zgodovino, 3/3-4, 1923, str. 100-112 (ponatis: Stanko VURNIK, Ivana Kobilca. Spomini, Ivana Kobilca. 1861-1926, Narodna galerija, Ljubljana 1979, str. 52-61); Silva TRDINA, Ivana Kobilca, Zbornik za umetnostno zgodovino, n. v. 2, 1952, str. 94114; Polonca VRHUNC, Življenje in delo Ivane Kobilce, Ivana Kobilca 1979 (op. 3), str. 22-25; Sandra BRATUŠA, Nataša CIBER, Veličastno neprilagojena umetnica. Življenjepis Ivane Kobilca (1861-1926), Ivana Kobilca 1861-1926. „Slikarija je vendar nekaj lepega ...«, Narodna galerija, Ljubljana 2018, str. 11-46.

4 Kobilca se je kmalu po prihodu povezala s slikarjem in likovnim urednikom revije Nada Ewaldom ArndtomTscheplinom (1865-1922), vodjo muzeja in mestnim svetnikom Konstantinom von Hörmannom (1850-1921), med bivanjem v Sarajevu pa se je uveljavila pri samem vrhu bosanske administracije, npr. pri Hugu baronu Kutscheri (1847-1909), civilnem upravitelju Bosne in Hercegovine, in Eugenu baronu Alboriju (1838-1915), upravitelju deželne vlade Bosne in Hercegovine. Mateja MAUČEC, Ivana Kobilca v Sarajevu (1897-1905), Ivana Kobilca 2018 (op. 3), str. 180-184.

5 Die Österreichisch-ungarische Monarchie in Wort und Bild. 22: Bosnien und Herzegowina, Wien 1901; Beti ŽEROVC, Zelo slovenska slika, Razgledi, 15, 1998, str. 24-25; Beti ŽEROVC, Ivana Kobilca and Her Painting for the Ljubljana Town Hall, Slovenia Bows to Ljubljana, in the Context of Women's Painting in the Late Nineteenth Century, Radovi Istituta za povijesti umjetnosti, 37, 2013, str. 167-178. 
se je vrnila $\mathrm{v}$ domovino, leto in pol pozneje pa se je preselila v Berlin, kjer je ostala do začetka prve svetovne vojne. Ob izbruhu vojne se je slikarka vrnila v Ljubljano, kjer je ostala do smrti. ${ }^{6}$

Poglavitni razlog, zaradi katerega je Ivana Kobilca leta 1897 odšla v Sarajevo, naj bi bilo po mnenju večine raziskovalcev naročilo portreta nadškofa Stadlerja. ${ }^{7}$ Prvi sarajevski nadškof dr. Josip Stadler (1843-1918, nadškof od 1881) je bil ključna figura v zgodovini bosensko-hercegovske Katoliške cerkve in je s svojim delovanjem posegel na vsa področja cerkveno-političnega, socialnega in političnega življenja (sl. 1). ${ }^{8}$ Povezava s Stadlerjem je bila za slikarko izjemnega pomena, saj je nadškof umetnico vključil tudi $\mathrm{v}$ izvedbo slikarskega programa semeniške cerkve sv. Cirila in Metoda v Sarajevu. ${ }^{9}$

Gradnja semeniške cerkve sv. Cirila in Metoda je predstavljala del širšega projekta reorganizacije katoliške hierarhije $\mathrm{v}$ Bosni in Hercegovini, ki je sledila avstroogrski okupaciji dežele. Leta 1878 je Avstro-Ogrska z od-

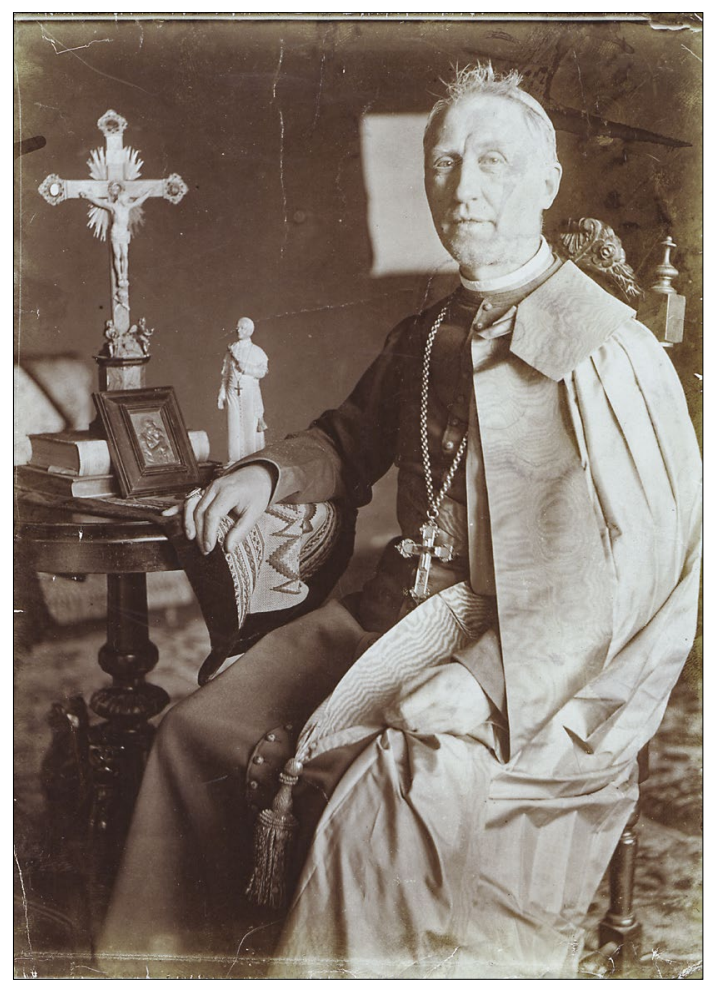

1. Dr. Josip Stadler (1843-1918), Arhiv Republike Slovenije ločbo Berlinskega kongresa pridobila mandat za zasedbo Bosne in Hercegovine in sledila je okupacija gospodarsko zaostale in politično nemirne dežele, ki je formalno še naprej spadala pod Osmansko cesarstvo. Avstroogrska oblast je skušala deželo modernizirati in jo integrirati $\mathrm{v}$ dualistični državni sistem z vpeljavo moderne uprave, vključitvijo $\mathrm{v}$ carinsko unijo, tehnološko modernizacijo, izgradnjo prometne infrastrukture, industrije ter z ukrepi na kulturnem področju. Dodaten izziv sta predstavljali večnacionalnost in večkonfesionalnost prebivalstva, saj je bila katoliška veroizpoved manjšinska, po številčnosti na tretjem mestu, za srbsko pravoslavno in muslimansko, dežela pa je bila predmet srbskih in hrvaških nacionalističnih apetitov. ${ }^{10}$

Spremenjene politične okoliščine so terjale spremembe tudi na verskem področju. Dotedanja ureditev, kjer je bilo katolištvo v Bosni in Hercegovini pod okriljem frančiškanskega reda, se je

6 VRHUNC 1979 (op. 3), str. 22-25.

7 TRDINA 1952 (op. 3), str. 102-103; VRHUNC 1979 (op. 3), str. 22; Ljerka MENAŠE, Luc MENAŠE, Ivana Kobilca, Gorenjski muzej, Kranj 1972, str. 41.

8 O nadškofu Stadlerju gl. Srečko Matko ĐAJA, Bosnien-Herzegowina in der österreichisch-ungarischen Epoche (1878-1918). Die Intelligentsia zwischen Tradition und Ideologie, München 1994, str. 50; Josip Stadler - Život $i$ djelo (ur. Pavo Jurišić), Sarajevo 1999; Zoran GRIJAK, Politička djelatnost vrhbosanskog nadbiskupa Josipa Stadlera, Zagreb 2001.

9 VURNIK 1923 (op. 3), str. 109; TRDINA 1952 (op. 3), str. 106.

10 ĐAJA 1994 (op. 8), str. 37-42; Leften STAVRIJANOS, Balkan posle 1453. godine, Beograd 2005, str. 375-405, 428-445; Ivo GOLDSTEIN, Hrvaška zgodovina, Ljubljana 2008 (Zgodovina držav in narodov, 3), str. 143-172; Sima M. ČIRKOVIĆ, Srbska zgodovina, Ljubljana 2009 (Zgodovina držav in narodov, 4), str. 196-208. 
izkazala za neustrezno in potrebna je bila vzpostavitev celovite cerkvene hierarhije, ki bi okrepila katolištvo na mejnem območju in tvorila po religiozni plati obrambni zid proti Pravoslavni cerkvi, po politični pa proti Rusiji. ${ }^{11}$ Nova ureditev Katoliške cerkve v Bosni in Hercegovini je bila po eni strani pomembno notranjepolitično vprašanje Avstro-Ogrske, v reševanje katerega so bili vključeni predstavniki avstrijske in ogrske vlade, po drugi strani pa je bilo vprašanje velikega pomena za Sveti sedež, ki se je nadejal okrepitve katolištva v jugovzhodni Evropi in je okupacijo dežele dojemal kot prvi korak k doseganju tega cilja. S sodelovanjem obeh strani je bil oblikovan program cerkvene reorganizacije, nato pa je bila 5. julija 1881 s papeško bulo Ex hac augusta ustanovljena v Bosni in Hercegovini posebna cerkvena pokrajina, ki je obsegala novoustanovljeno vrhbosensko nadškofijo s sedežem v Sarajevu in tri sufraganske škofije. ${ }^{12}$ Sestavni del programa je bila izgradnja stolnice ter vzpostavitev stolnega kapitlja in semenišča v Sarajevu, določene so bile tudi letne dotacije avstroogrske vlade za katoliške ustanove, cesar pa je dobil privilegij imenovanja nadškofa in škofov. ${ }^{13}$ Avstroogrskim oblastem je bil tako prepuščen velik vpliv ne samo na imenovanje nadškofa, temveč tudi na nadzor njegovega delovanja ter delovanja ostalih škofov. ${ }^{14}$

Pri načrtovanju reorganizacije cerkvenega ustroja v Bosni in Hercegovini je treba omeniti tudi vlogo drugega cerkvenega odličnika, bosensko-sremskega škofa Josipa Juraja Strossmayerja (18151905, škof od 1850), ki je rezidiral v slavonskem Đakovu. ${ }^{15}$ Strossmayer je že na osnovi svojega škofovskega naziva menil, da mu pripada pravica do sodelovanja v razpravi o tem vprašanju, vendar je bil njegov položaj problematičen, saj se je kot glasen zagovornik panslavistične ideje zameril avstroogrskim oblastem, ki so njegovo politično delovanje spremljale z veliko nenaklonjenostjo. ${ }^{16}$ Strossmayer je prek svojih prijateljev posredoval papežu svoje predloge nove cerkvene ureditve $\mathrm{v}$ Bosni in Hercegovini, vendar mu je Sveti sedež, čeprav je njegove predloge pregledal, dal jasno vedeti, da ne namerava ničesar narediti brez soglasja avstroogrske vlade in da zaradi nenaklonjenosti avstroogrske politike Strossmayerju njegovih predlogov na Dunaju ne bo predstavljal. ${ }^{17}$

Kot že omenjeno, je bil za imenovanje vrhbosenskega nadškofa potreben konsenz tako Svetega sedeža kot tudi avstroogrskih oblasti. Ta zahteva je izločila številne kandidate iz vrst frančiškanskega reda. Papež Leon XIII. (1810-1903, papež od 1878) je bil mnenja, da bosensko-hercegovski frančiškani niso dorasli reorganizacijskim zahtevam, in se je nagibal $\mathrm{k}$ izboru osebe iz vrst svetne duhovščine $s$ področja Hrvaške ali Slavonije. ${ }^{18}$ Avstro-Ogrska, ki je nameravala v Bosni in Hercegovini voditi politiko

11 Andreas GOTTSMANN, Rom und die nationalen Katholizismen in der Donaumonarchie. Römischer Universalismus, habsburgische Reichspolitik und nationale Identitäten 1878-1914, Wien 2010, str. 77-81.

12 Sufraganske škofije so bile v Mostarju, Banjaluki in Trebinju, a je slednja ostala pod administracijo dubrovniške škofije; gl. GRIJAK 2001 (op. 8), str. 80.

13 Imenovanje apostolskega administratorja škofije Banjaluka je ostalo v pristojnosti Svetega sedeža; gl. GRIJAK 2001 (op. 8), str. 80.

14 GRIJAK 2001 (op. 8), str. 80.

15 Novejša dela o Strossmayerju: Zbornik radova o Josipu Jurju Strossmayeru (ur. Ivo Padovan), Zagreb 1997; William Brooks TOMLJANOVICH, Biskup Strossmayer. Nacionalizam i moderni katolicizam u Hrvatskoj, Zagreb 2001; Medunarodni znanstveni skup Josip Juraj Strossmayer povodom 190. obljetnice rodenja i 100. obljetnice smrti. Zbornik radova (ur. Franjo Šanjek), Zagreb 2006.

16 GRIJAK 2001 (op. 8), str. 41.

17 GRIJAK 2001 (op. 8), str. 46-52.

18 Frančiškanskemu redu niso bili naklonjeni niti v avstroogrski diplomaciji, saj so zaradi povezovanja dela bosenskih frančiškanov $\mathrm{z}$ južnoslovanskimi nacionalnimi gibanji videli red kot politično nezanesljiv, zaradi načina izbire redovnega vodstva pa tudi težko obvladljiv; gl. ĐAJA 1994 (op. 8), str. 47. 
mednacionalnega in medkonfesionalnega ravnotežja, je Sveti sedež pri izboru precej omejevala, saj so bili zanjo izrazito hrvaško opredeljeni kandidati nesprejemljivi, kar je zopet izločilo več kandidatov. ${ }^{19}$ Na priporočilo hrvaškega bana Ladislava Pejačevića (1824-1901) je bil za nadškofa predlagan dr. Josip Stadler. Slovan nemškega porekla (rodbina izvira iz Gornjega Porenja) z doktoratom iz filozofije in teologije na papeški univerzi Gregoriani je bil zaradi visoke izobrazbe in konservativnih stališč primerna izbira tako za avstroogrsko oblast, ki je od njega pričakovala servilnost, kot tudi za Sveti sedež, ki ga je prepričal s svojim znanstvenim delom. ${ }^{20}$ Kot profesor ontologije in fundamentalne teologije na Teološki fakulteti v Zagrebu se je ukvarjal s temami, kot so problem prave vere, prave Kristusove Cerkve ter katoliškega nauka o papežu in vprašanja cerkvene unije s Pravoslavno cerkvijo, tj. s temami, ki so bile za papeške načrte glede cerkvene združitve ključnega pomena, o čemer bo govor v nadaljevanju. ${ }^{21}$ Nad Stadlerjevim imenovanjem Strossmayer ni bil pretirano navdušen, saj je dvomil, da se bo bodoči nadškof znal upreti političnim pritiskom, kar se je v sledečih letih izkazalo za povsem napačno oceno. ${ }^{22}$

16. avgusta 1881 je bil Stadler imenovan za prvega vrhbosenskega nadškofa. Njegov prvi projekt je bila izgradnja katedrale Srca Jezusovega, ki je bila zgrajena med letoma 1884 in $1889 .{ }^{23}$ Gradnja stolnice je v Sarajevo pripeljala na Dunaju šolanega hrvaškega arhitekta Josipa Vancaša pl. Požeškega (1859-1932), ki je dobro sodelovanje s Stadlerjem nadaljeval in leta 1891 izdelal tudi načrte za cerkev sv. Cirila in Metoda. ${ }^{24}$ Že pri gradnji stolnice so se pokazale finančne omejitve, ki so Stadlerja prisilile v iskanje sredstev iz drugih virov, ne samo državnega financiranja. Novoustanovljena nadškofija namreč ni imela lastnih finančnih virov in za pomoč se je Stadler obrnil tudi na Strossmayerja, ki je z bogato mecensko podporo pomagal ne samo pri gradnji stolnice, temveč tudi pri številnih projektih, ki so sledili, med drugim pri gradnji in opremi cerkve sv. Cirila in Metoda. ${ }^{25}$

Ker je bil Strossmayer velik mecen hrvaške umetnosti v 19. stoletju, se je smiselno vprašati, v kolikšni meri je vplival na izbor umetnikov, ki jih je Stadler najel za opremo cerkva. Med letoma 1866 in 1882 je bila zgrajena đakovska katedrala, Strossmayerjev osebni projekt, za katerega je angažiral (po svojih kriterijih) najboljše arhitekte in umetnike. ${ }^{26}$ Kot velik ljubitelj nazarenskega slikarstva, s katerim je prišel v stik že v času študija na Dunaju, je k likovni opremi pritegnil Johanna Friedricha Overbecka (1789-1869), ki pa se je zaradi visoke starosti (v času dogovarjanja za poslikave je štel že 77 let) omejil na izdelavo kartonov. ${ }^{27}$ Dokončanje dela in realizacijo fresk je Strossmayer

19 GRIJAK 2001 (op. 8), str. 81-83.

20 GRIJAK 2001 (op. 8), str. 81-84. Jezuitski red je vplival na Stadlerjevo teološko formacijo in čeprav nikoli ni bil jezuit, je ostal celo življenje izrazito povezan z njimi. Prim. Zoran GRIJAK, Mladost vrhbosanskog biskupa Josipa Stadlera, Časopis za suvremenu povijest, 31/1, 1999, str. 19.

${ }^{21}$ GRIJAK 2001 (op. 8), str. 105-106.

22 GRIJAK 2001 (op. 8), str. 85.

23 Đuro BASLER, Katedrala u Sarajevu, Sarajevo 1989, str. 17; Dragan DAMJANOVIĆ, Neogotićka arhitektura Josipa Vancaša u Bosni i Hercegovini, Prostor, 22/1, 2014, str. 99-103.

24 Jela BOŽIĆ, Arhitekt Josip pl. Vancaš. Značaj i doprinos arhitekturi Sarajeva u periodu austrougarske vladavine, Sarajevo 1989 (tipkopis doktorske disertacije), str. 165.

25 Angela SZABO, Biskup Strossmayer i njegova suradnja s nadbiskupom Josipom Stadlerom, Marulić. Časopis za književnost $i$ kulturu, 48/4, 2015, str. 11-12.

26 O đakovski katedrali gl. Dragan DAMJANOVIĆ, Đakovačka katedrala, Zagreb 2009; Dragan DAMJANOVIĆ, Umjetničko blago Strossmayerove katedrale u Đakovu, Đakovo 2017.

27 Strossmayer se je s slikarjem sprva želel predvsem posvetovati glede ikonografskega programa, Overbeck pa se je, navdušen nad priložnostjo, da bi sodeloval pri tako velikem projektu, sam ponudil, da bi ne samo sestavil ikonografski program, temveč tudi pripravil kartone za freske; gl. DAMJANOVIĆ 2009 (op. 26), str. 305-306. 
zaupal Alexandru Maximilianu Seitzu (1811-1888) in njegovemu sinu Ludwigu (1844-1908), slikarjema iz ožjega Overbeckovega kroga, ki sta bila specializirana za slikanje fresk. ${ }^{28}$

Pri izbiri umetnikov se je Strossmayer opiral tudi na svojega prijatelja Nikolo Voršaka (18361880), kanonika zavoda sv. Hieronima v Rimu, ki je pogosto nastopal kot njegov svetovalec ter posrednik pri nakupu umetnin. ${ }^{29} \mathrm{~V}$ sedemdesetih letih se je ožjemu krogu škofovih svetovalcev pridružil še slikar in umetnostni zgodovinar Isidor Kršnjavi (1845-1927), ki je skušal vplivati na njegove odločitve v smeri večjega angažiranja »domačih « umetnikov, tj. umetnikov slovanskega porekla. ${ }^{30}$ Deloma ga je k temu vodil osebni interes (upal je, da mu bo pri delih na katedrali uspelo tudi zase pridobiti kakšno naročilo), deloma pa zato, ker je skušal gradnjo đakovske katedrale uporabiti za izhodišče preporoda hrvaške umetnosti. Kršnjavi, ki je v Strossmayerjevih očeh užival velik ugled, je igral na karto škofovega domoljublja in ga tako prepričeval: »Bog zna biste li excelentissime uz prevelike, nebrojene i riedke Vaše zasluge tom prilikom i tu još stekli, da biste iznašli kakvog mladog Rafaela slavenskog, koji sad valjda kakve male sličice na prodaju slikati mora negdje u Parizu ili Monakovu. $\aleph^{31}$ Strossmayerjevo stališče je bilo drugačno, dela domačih umetnikov po njegovem niso dosegala zahtevane kvalitete in verjel je, da bo $\mathrm{z}$ angažiranjem svetovno priznanih umetnikov $\mathrm{v}$ đakovski katedrali ustvarjen večji doprinos $\mathrm{k}$ razvoju hrvaške umetnosti, kot bi bil z najemanjem domačih umetnikov povprečne kvalitete. Trud Kršnjavega, da bi za opremo stolnice pridobili več domačih umetnikov, je bil tako neuspešen, saj je bilo Strossmayerjevo stališče do poslikave cerkve jasno definirano in dosledno, čeprav v obravnavanem času že precej konservativno. ${ }^{32}$

Leta 1882, ko je bila posvečena đakovska katedrala, je bil ustoličen tudi prvi nadškof vrhbosenske nadškofije, Josip Stadler. Stadler je v sodelovanju z avstroogrsko oblastjo, tj. s finančnim ministrstvom, takoj začel z zbiranjem sredstev za gradnjo katedrale v Sarajevu. ${ }^{33} \mathrm{~K}$ sodelovanju je bilo povabljenih več arhitektov, med njimi tudi Friedrich baron Schmidt (1825-1891), ki je v Đakovu nasledil preminulega glavnega arhitekta Karla Rösnerja (1804-1869). Schmidt k projektu zaradi obilice dela ni pristopil, je pa priporočil svojega učenca Josipa Vancaša pl. Požeškega. ${ }^{34}$ Kot je bilo tedaj pri pomembnejših sakralnih naročilih običajno, je Vancaš poleg same arhitekture projektiral

28 DAMJANOVIĆ 2017 (op. 26), str. 64. Za Alexandra Maximiliana in Ludwiga Seitza gl. Artur SCHNEIDER, Strossmayer i religiozno slikarstvo njemačkih nazarenaca, Rad Jugoslavenske akademije znanosti $i$ umjetnosti Umjetničkoga razreda, 1 (252), 1935, str. 31-38.

29 SCHNEIDER 1935 (op. 28), str. 5.

30 Tudi Voršak, ki je živel v Rimu, je okoli sebe zbiral Hrvate, ki so se zadrževali v večnem mestu, in je Strossmayerju pogosto priporočal hrvaške umetnike za đakovsko katedralo ali naročilo za škofovo galerijo, tako da so pri nekaterih umetnikih pobude za vključitev prihajale z obeh strani, od Kršnjavega in Voršaka; gl. Dragan DAMJANOVIĆ, Iso Kršnjavi i opremanje đakovačke katedrale, Zbornik Odsjeka za povijesne znanosti Zavoda za povijesne i društvene znanosti Hrvatske akademije znanosti i umjetnosti, 26, 2008, str. 197. O Isidorju Kršnjavem gl. Izidor KRŠNJAVI, Autobiografija, Vijenac, 7/5, 1927, str. 112-117; Iso Kršnjavi - veliki utemeljitelj. Zbornik radova znanstvenog skupa (ur. Ivana Mance, Zlatko Matijević), Zagreb 2015.

31 DAMJANOVIĆ 2008 (op. 30), str. 202.

32 Kršnjavi je bil mnenja, da je mogoče tudi med slovanskimi umetniki najti takšne, ki bi bili zmožni sodelovati tako pri poslikavi katedrale kot tudi pri njeni kiparski opremi. Med predlaganimi umetniki so bili tako češki (Vojtěch Hynais (1854-1925), Jaroslav Čermák (1831-1878)) in poljski (Jan Alojzy Matejko (1838-1893)) kot tudi domači umetniki (Ferdinand von Quiquerez-Beaujeu (1845-1893)); gl. DAMJANOVIĆ 2008 (op. 30), str. 201-209.

33 BASLER 1989 (op. 23); Andrea BAOTIĆ, Prvostolna crkva Srca Isusova - sarajevska katedrala, Radovi hrvatskog društva za znanost $i$ umjetnost, 11, 2009, str. 57-78.

34 BAOTIĆ 2009 (op. 33), str. 59, 63, 68. O Vancašu gl. BOŽIĆ 1989 (op. 24); Dragan DAMJANOVIĆ, Neogotička arhitektura u opusu Josipa Vancaša. Radovi u Italiji, Hrvatskoj i Sloveniji, Prostor, 22/2, 2014, str. 252-267. 
tudi cerkveno opremo. Glede na to, da je đakovska cerkev slovela kot eden najmonumentalnejših primerov historizma na Hrvaškem in postala vzor cerkvene arhitekture v širši regiji, ne preseneča, da je Stadler tudi za sarajevsko katedralo želel pridobiti umetnike, ki jim je že Strossmayer zaupal okrasitev »svoje« cerkve. Na Stadlerjevo odločitev je nedvomno močno vplival tudi Vancaš, ki je že v izhodišču želel zaposliti »iste mojstre, ki so delali v Đakovu«. ${ }^{35} \mathrm{Za}$ danes skoraj povsem uničeno slikarsko opremo sarajevske katedrale so bili tako najeti Alexander Maximilian Seitz in njegov sin Ludwig ter Alexandrov pomočnik Alberto de Rohden za figuralno poslikavo, za dekorativno pa Josip Voltolini (1838-1892) in Ivan Betizza. ${ }^{36}$ Tako deželna vlada kot tudi nadškof sta bila s končnim rezultatom zadovoljna, saj je bil Vancaš za svoj prispevek leta 1890 odlikovan z viteškim križcem reda Franca Jožefa I., postal pa je tudi uradni arhitekt vrhbosenske nadškofije. ${ }^{37}$

Izgradnji sarajevske stolnice je sledila ustanovitev deželnega semenišča s cerkvijo sv. Cirila in Metoda. ${ }^{38}$ Stadler je že v času gradnje sarajevske katedrale kupil zemljišče za semenišče ter dal Vancašu izdelati načrte, vendar do gradnje zaradi finančnih težav ni prišlo. Celotni kompleks je bil zgrajen šele v letih 1893-1896, pri čemer je bil del, namenjen šolski dejavnosti, dozidan in naseljen že leta 1893, cerkev, ki je umeščena med obe krili semenišča, pa je bila dokončana in posvečena leta 1896. ${ }^{39} \mathrm{Ob}$ posvetitvi cerkve so notranjščino krasili samo glavni oltar, prižnica in stranska oltarja, posvečena Mariji in Srcu Jezusovemu, poslikava in preostala oprema pa so sledili pozneje. ${ }^{40}$ Figuralna poslikava je delo dveh avtorjev, Ivane Kobilce in Otona Ivekovića (1869-1939), ${ }^{41}$ dekorativno pa je prispeval Karl Richter. ${ }^{42}$

Pri likovni opremi sarajevske katedrale je šlo za neposreden prenos Strossmayerjevih izbir, za cerkev sv. Cirila in Metoda pa je Stadler izbral povsem drugo skupino umetnikov, zato se na tem mestu pojavlja vprašanje, kaj je vplivalo na takšno odločitev in ali je v njej mogoče iskati tudi Strossmayerjev vpliv. Strossmayer ni bil samo nesporna avtoriteta kot poznavalec umetnosti, za Stadlerja je bil izjemno pomemben predvsem kot sodelavec in podpornik njegovega dela. Prvotna

35 BAOTIĆ 2009 (op. 33), str. 68.

36 Kako neposredno je bilo zgledovanje po đakovski katedrali, priča tudi detajl, da je Rohden naslikal nekatere kompozicije kar po kartonih, nastalih za đakovsko katedralo. Prvotna poslikava sarajevske stolnice je ohranjena le v rekonstruirani obliki, v izvorni obliki je ohranjenih le še osem tondov, ki jih je izdelal Ludwig Seitz. Gl. BAOTIĆ 2009 (op. 33), str. 68-69.

37 BAOTIĆ 2009 (op. 33), str. 78.

38 Razlog za dokaj pozno ustanovitev semenišča v Sarajevu je, da sta bila v Travniku leta 1882 ustanovljena jezuitska gimnazija in deško semenišče, leta 1890 pa še semenišče, ki je bilo kasneje prestavljeno v Sarajevo; gl. GRIJAK 2001 (op. 8), str. 116.

39 O stavbni zgodovini semenišča gl. BOŽIĆ 1989 (op. 24), str. 165-169.

40 Andrea BAOTIĆ, Neostilska sakralna oprema bogoslovne crkve sv. Ćirila i Metoda, 120. obljetnica Bogoslovije. Znanstveni skup povodom obilježevanja 120. obljetnice organiziranog filozofsko-teološkog studija na Vrhbosanskoj katoličkoj bogosloviji (ur. Darko Tomašević), Sarajevo 2011, str. 196.

${ }^{41}$ O Ivekoviću gl. Ljubica MLADENOVIĆ, Građansko slikarstvo u Bosni i Hercegovini u XIX. veku, Sarajevo 1982, str. 52.

42 Aus dem Occupationsgebiete, Agramer Zeitung, 72/188, 18. 8. 1897, str. 5. Kljub omenjanju Bocarića kot avtorja figuralne poslikave (BOŽIĆ 1989 (op. 24), str. 167) ali ornamentike (Crkva Svetog Ćirila i Metoda sa Bogoslovijom, http://www.kons.gov.ba/main.php?id_struct=6\&lang=1\&action=view\&id=3335 (25.10.2013)) viri njegove udeležbe pri poslikavi cerkve ne izpričujejo. Ivana UDOVIČIĆ, Zidno slikarstvo u crkvi sv. Ćirila i Metoda u Sarajevu, 120. obljetnica Bogoslovije. Znanstveni skup povodom obilježevanja 120. obljentice organiziranog filozofsko-teološkog studija na Vrhbosanskoj katoličkoj bogosloviji (ur. Darko Tomašević), Sarajevo 2011, str. 125, piše tudi, da je dekoracijo sten naredil Leo Arndt, vendar ne navaja vira za to trditev; v ohranjenih virih se Arndtovo sodelovanje ne omenja. 
zadržanost, ki jo je Strossmayer kazal do vrhbosenskega nadškofa, se je z leti sodelovanja spremenila v globoko vzajemno spoštovanje in Strossmayerjevo podpiranje Stadlerjevega dela v Bosni in Hercegovini, tako moralno kot tudi s finančnimi sredstvi. ${ }^{43}$ Zdi se verjetno, da se je Stadler, ki je tudi pri tej cerkvi zaprosil Strossmayerja za finančno pomoč in ga povabil k posvetitvi cerkve, nanj obrnil tudi za nasvet glede izbire umetnikov. ${ }^{44}$

Nedvomno so omejena finančna sredstva, ki so nadškofa prisilila v etapno gradnjo semeniškega kompleksa, vplivala tudi na prvo izbiro, ko je za figuralno poslikavo izbral v Sarajevu delujočega portretista in slikarja ikon Anastasa Bocarića (1864-1944), odprto pa ostaja vprašanje, ali je bil morda Strossmayer tisti, ki je Stadlerjevo izbiro preusmeril na Kobilco in Ivekovića. ${ }^{45}$ Iveković je bil kot učenec Quiquereza in s specializacijo v historičnem slikarstvu nedvomno primernejša izbira za poslikavo cerkve. ${ }^{46}$ Kobilca s sicer skromnimi referencami na področju sakralnega slikarstva in kot šlana portretistka resda ni bila najbolj kvalificirana izbira, vendar so njeni mednarodni razstavljalski uspehi pričali o neovrgljivi kvaliteti njenih del. ${ }^{47} \mathrm{Da}$ bi Strossmayer priporočil ta dva slikarja, se zdi povsem mogoče, saj je Kobilco osebno spoznal že na začetkih njene razstavljalske poti, ko je leta 1890 razstavljala v prostorih Jugoslovanske akademije znanosti in umetnosti v Zagrebu, skoraj zagotovo pa je poznal tudi Ivekovića, nekdanjega varovanca Kršnjavega, ki je takrat spadal v krog slikarjev okoli Vlaha Bukovca. ${ }^{48}$

Poslikava semeniške cerkve je bila med slikarja porazdeljena na dva po obsegu primerljiva dela. Oton Iveković je naslikal monumentalne freske s prizori iz življenja sv. Cirila in Metoda. V luneti nad oltarjem sv. Jožefa v zahodnem kraku transepta je naslikan prizor sv. Cirila in Metoda pri moravskemu knezu Rastislavu, v jukstapoziciji na vzhodni strani pa Sv. Ciril in Metod pred papežem Hadrijanom II. V vencu tamburja je naslikanih osem prizorov iz Kristusovega življenja: Oznanjenje, Obiskovanje, Rojstvo, Darovanje v templju, Dvanajstletni Jezus v templju, Čudežni ribolov, Kristus nosi križ in Vstajenje. Njegovo delo so tudi evangelisti na pendentivih kupole. ${ }^{49}$

Ivana Kobilca je izvedla freski v polkrožno zaključenih poljih nad stranskima oltarjema, in sicer Zedinjenje Cerkve ter Češčenje Marije (z jezuitskimi svetniki). ${ }^{50}$ Poslikala je tudi kupolo, kjer je po vzoru Michelangelovega Stvarjenja sveta naslikala Boga Očeta v sferični perspektivi. Njeno delo so tudi štirje tondi, dva na stenah pevskega kora in dva na stranskih emporah. $\mathrm{V}$ tondu na zahodni empori, obrnjeni proti freski s prizorom Zedinjenje Cerkve, je moč prepoznati Konstantina Velikega.

43 V Strossmayerjevi zapuščini so ohranjena številna Stadlerjeva pisma, v katerih se škofu zahvaljuje za njegovo dobrodelnost, posebej v času izgradnje bogoslovnega semenišča; gl. GRIJAK 2001 (op. 8), str. 640.

44 Kako tesna je bila njuna povezanost, priča tudi podatek, da je bil ob Strossmayerjevem pogrebu Stadlerju zaupan poslovilni govor. O Stadlerjevem sodelovanju s Strossmayerjem gl. SZABO 2015 (op. 25), str. 14.

45 Mali vjesnik, Sarajevski list, 11/145-146, 4. 12. 1896, s. p. O Bocariću gl. MLADENOVIĆ 1982 (op. 41), str. 117-120. Vancaš je na Stadlerjevo zahtevo zaradi omejenih sredstev že na začetku predvidel etapno gradnjo; prim. BOŽIĆ 1989 (op. 24), str. 165.

46 Niko P. TOZI, Iveković Oton, Enciklopedija likovnih umjetnosti, 3, Zagreb 1964, str. 43.

47 Med redkimi primeri njenih sakralnih del sta dve Brezmadežni iz ok. leta 1895, ki se nahajata v ž. c. sv. Lenarta v Kropi in p. c. Marije sedem žalosti v Podbrezjah; gl. BRATUŠA, CIBER 2018 (op. 3), str. 24.

48 Snježana PINTARIĆ, Iveković, Oton, Hrvatski biografski leksikon, http://hbl.lzmk.hr/clanak.aspx?id=118 (10. 11. 2020); BRATUŠA, CIBER 2018 (op. 3), str. 18. Beti ŽEROVC, The Exhibition of Ivana Kobilca in Zagreb in 1890, Peristil, 57, 2014, str. 154, sklepa, da je Strossmayer verjetno prispeval k uveljavitvi Kobilce znotraj cerkvenih krogov.

49 MLADENOVIĆ 1982 (op. 41), str. 53.

50 Ljerka MENAŠE, Umetniški razvoj Ivane Kobilce, Zbornik za umetnostno zgodovino, n. v. 2, 1952, str. 138. 


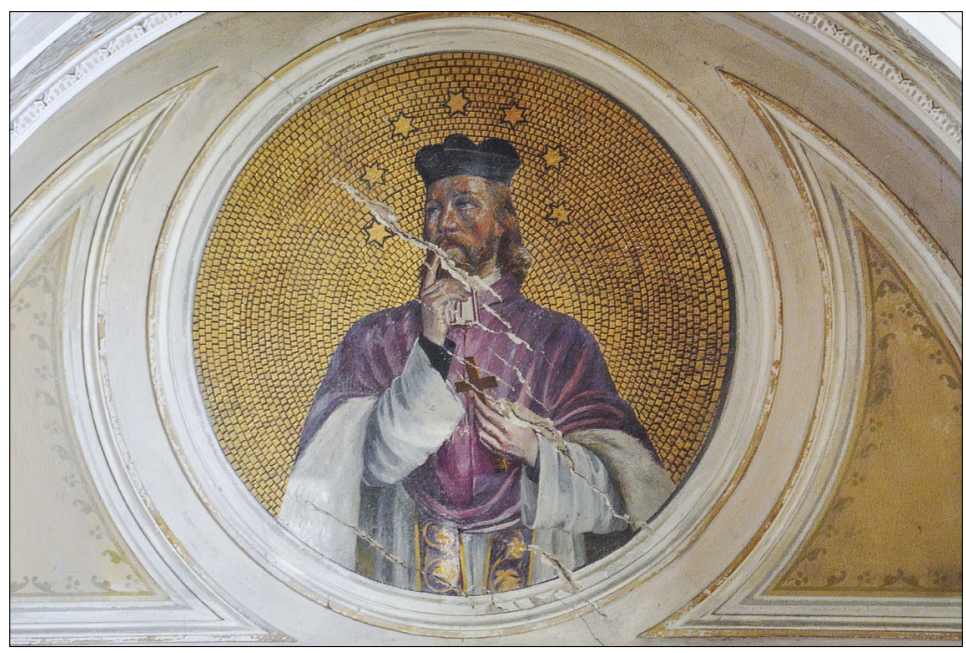

2. Ivana Kobilca:

Sv. Janez Nepomuk, 1898, semeniška cerkev sv. Cirila in Metoda, Sarajevo

Gre za profilno upodobljenega moškega z lovorjevim vencem, rotulusom v roki ter s križem v ozadju, na drugi strani cerkve pa je $v$ jukstapoziciji upodobljena ženska figura v kraljevskem plašču s križem v rokah, sv. Helena. Na pevskem koru se na nasprotnih straneh nahajata poprsji svetnikov. Na zahodni strani je podoba starejšega bradatega moškega v vijolični moceti, s knjigo in peresom v rokah. Oblačila kažejo na svetnika zahodne cerkve, vendar pa upodobljeni atributi ne zadoščajo za njegovo identifikacijo. Na drugi strani je v tondu upodobljeno poprsje sv. Janeza Nepomuka s prstom na ustih in vencem zvezd okoli glave (sl. 2). ${ }^{51}$

Oba slikarja sta freske signirala in datirala. Iveković se je podpisal in z letnico 1897 označil prizor Darovanja v templju, ki je naslikan v tamburju. Podpisal se je tudi na prizora sv. Cirila in Metoda pri moravskem knezu Rastislavu in sv. Cirila in Metoda pred papežem Hadrijanom II., ki pa sta oba datirana leto kasneje. ${ }^{52}$ Kobilca je signirala in datirala fresko $\mathrm{z}$ motivom Zedinjenja Cerkve v levem spodnjem kotu, vendar je zob časa letnico preveč uničil, da bi jo bilo mogoče $\mathrm{z}$ gotovostjo prebrati. Potek poslikav se sklada z objavo v lokalnem časopisu Bosnische Post, in sicer da je avgusta 1897 Kobilca pripravljala kartone za podobo Boga Očeta za fresko v kupoli, Iveković pa kartone za freske $v$ tamburju. Ta dela naj bi bila zaključena $v$ roku desetih tednov, nato pa je bila predvidena še poslikava lunet in sten nad stranskima oltarjema. ${ }^{53}$ Poslikava semeniške cerkve je očitno potekala zelo hitro, saj je Ivana Kobilca v pismu sestri marca 1898 omenila, da mora pripraviti skico za cerkev ${ }^{54}$ mesec pozneje pa potožila, da jo »g. biskup grozno priganja.${ }^{55} \mathrm{~V}$ pismih je moč najti še podatek, da je slikarka začela delati drugo podobo v cerkvi v začetku septembra $1898 .{ }^{56}$ $\mathrm{Na}$ podlagi korespondence je mogoče sklepati, da je bila glavnina Kobilčinih poslikav narejena $\mathrm{v}$ letih $1897-1898 .^{57}$

51 MAUČEC 2018 (op. 4), str. 171-200.

52 UDOVIČIĆ 2011 (op. 42), str. 145, 149, 153.

53 Aus dem Occupationsgebiete 1897 (op. 42), str. 5.

54 Pismo Ivane Kobilce Mariji Pintar, 24. 3. 1898, zasebna last.

55 Pismo Ivane Kobilce Mariji Pintar, 24. 4. 1898, zasebna last.

56 Pismo Ivane Kobilce Mariji Pintar, 4. 9. 1898, zasebna last.

57 Leta 1896 sta bila za poslikavo cerkve napovedana Anastas Bocarić in Karl Richter, ki naj bi izdelala figuralno in dekorativno stensko poslikavo; gl. Mali vjesnik 1896 (op. 45), s. p. 
Freske v semeniški cerkvi so tako eno prvih naročil, ki jih je Kobilca dobila v Sarajevu. S tem se odpira vprašanje glavnega razloga za njen prihod $\mathrm{v}$ bosansko prestolnico, saj se $\mathrm{v}$ literaturi navajata dva: da je odšla v Sarajevo, ker je dobila naročilo za poslikavo obravnavane cerkve, ali da je bil vzrok naročilo portreta nadškofa Stadlerja, ki ga je naslikala istega leta. V stroki je prevladalo stališče, da je bil razlog za selitev naročilo portreta, ki je bil slavnostno izročen Stadlerju januarja 1898 ob šestnajsti obletnici imenovanja za nadškofa. ${ }^{58}$ Vendar pa časovno sosledje postavlja to razlago pod vprašaj: Kobilca se je namreč v Sarajevo preselila in si tam uredila atelje že maja 1897, več tednov pred povratkom nadškofa, ki je bil dlje časa odsoten zaradi bolezni. ${ }^{59}$

Po drugi strani pa je v svojih spominih, ki so nastali v zadnjih letih njenega življenja, Kobilca drugače opisala odhod v Sarajevo: "Vleklo me je ven in kdovezakaj mi je bilo Sarajevo, kamor sem kmalu po prihodu iz Firence odpotovala, tako pogodu? Tam sem po naročilu škofa dr. Stadlerja imela poslikati jezuitsko cerkev /.../« ter nadaljevala, "po naročilu sarajevskih Slovencev sem škofa enkrat portretirala, da so mu potem podarili sliko. « ${ }^{60} \mathrm{Iz}$ citata je mogoče sklepati, da je bilo poglavitno naročilo, ki je slikarko pripeljalo v Sarajevo, sodelovanje pri poslikavi cerkve in ne portretiranje nadškofa. Nekateri avtorji so sicer poskušali njen prihod v Sarajevo povezati z naročilom omenjenih fresk, a so ga hkrati pomikali v zgodnejši čas. V literaturi je mogoče najti navedbe, da je bila Kobilca v Sarajevu prisotna že od leta $1893^{61}$ oziroma da je prišla v Sarajevo, da bi sodelovala pri poslikavi cerkve, leta 1894. ${ }^{62}$ Obstaja možnost, da je Sarajevo obiskala že leta 1893 ali 1894, vendar v tem primeru obisk mesta ni mogel biti povezan s poslikavo semeniške cerkve, saj do leta 1897 za sodelovanje pri njej niti ni bila predvidena. Ožja časovna zamejitev nastanka fresk, ki se tako postavljajo blizu njeni selitvi v mesto, ter slikarkini spomini napeljujejo na domnevo, da je bila selitev v Sarajevo prej posledica naročila fresk kot nadškofovega portreta, vendar puščajo odprto vprašanje, kako je prišlo do Stadlerjeve izbire slikarjev. ${ }^{63}$

Tretji dejavnik, ki ga je pri Kobilčini selitvi v Sarajevo treba upoštevati, so širše ekonomsko-politične okoliščine, ki so iz zaspanega glavnega mesta province naredile živahno in hitro razvijajočo se prestolnico. Avstroogrska politika, ki je med argumenti za okupacijo dežele poudarjala »kulturno misijo«, je z modernizacijo mesta po vzoru evropskih prestolnic želela pokazati koristi dobrega vladanja

58 France MESESNEL, Kobilca Ivana, Slovenski biografski leksikon, 1/3 (ur. Izidor Cankar, Franc Ksaver Lukman), Ljubljana 1928, str. 477; MENAŠE, MENAŠE 1972 (op. 7), str. 41; VRHUNC 1979 (op. 3), str. 22; BRATUŠA, CIBER 2018 (op. 3), str. 25. TRDINA 1952 (op. 3), str. 102, navaja, da je bil glavni zagovornik Kobilčinega prihoda v Sarajevo za izdelavo portreta sanitetni svetnik Unterlugauer, vendar vir teh informacij ni naveden. Avtorica je pri pisanju članka sodelovala s slikarkino nečakinjo, ki je bila vir informacij o njenem življenju, verjetno pa je razpolagala tudi $z$ delom Kobilčine korespondence, ki naj bi bila po informacijah sorodnikov pozneje uničena.

59 Vrnitev nadškofa Stadlerja v Sarajevo, po treh mesecih odsotnosti, je dokumentirana 3. junija 1897 (Telegramme, Agramer Zeitung, 72/127, 4. 6. 1897, str. 3). Kobilca je v Sarajevu prvič omenjena hkrati z razstavo 17. maja 1897 (Gemälde Ausstellung, Bosnische Post, 14/112, 17. 5. 1897, str. 2), štiri dni pozneje pa je v istem glasilu omenjeno, da si namerava v Sarajevu urediti atelje (Sarajevoer Kunstleben, Bosnische Post, 14/116, 21. 5. 1897, str. 3).

60 VURNIK 1923 (op. 3), str. 109-110. Kobilca je v Firence za nekaj mesecev odpotovala spomladi 1894 (VURNIK 1923 (op. 3), str. 109). Čeprav so Vurnikovi Spomini biografski zapis, ki je nastal še v času njenega življenja, je v njih več primerov časovnega neskladja dogodkov, zato je treba zapis jemati s precej previdnosti.

${ }^{61}$ Hamdija KREŠEVLJAKOVIĆ, Sarajevo za vrijeme austrougarske uprave (1878-1918), Sarajevo 1969, str. 56; Rosa PFÄFFINGER, Die Pariser Bohème (1889-1895). Ein autobiographischer Bericht der Malerin Rosa Pfäffinger (ur. Ulrike Wolff-Thomsen), Kiel 2007, str. 126, op. 139.

62 MLADENOVIĆ 1982 (op. 41), str. 97. Pri tem je treba poudariti, da Ljubica Mladenović ne navaja vira za to tezo; trditev navaja v odstavku, povzetem po VRHUNC 1979 (op. 3), str. 22. Ta teza se ponavlja tudi v novejših delih; gl. Ivana JEVĐEVIĆ, Likovna umetnost, Četrta stran trikotnika. Slovenci v Bosni in Hercegovini. 1878-2000 (ur. Stanislav Koblar), Ljubljana 2008, str. 300.

${ }_{63}$ Teza je bila prvič objavljena v MAUČEC 2018 (op. 4), str. 174. 
in administracije za domačine in obiskovalce. ${ }^{64}$ Vzpostavitev finančne, administrativne in prometne infrastrukture je omogočila ekspanzijo gradbeništva, trgovine in industrije, posledično se je v mestu sedemnajst let po okupaciji število prebivalcev skoraj podvojilo. ${ }^{65}$ Ugodne ekonomske okoliščine, nagel porast prebivalstva in spodbudna kulturna politika, ki jo je vodila avstroogrska oblast v Bosni in Hercegovini, pa so imeli za posledico ugodne okoliščine tudi za umetnike, ki so prihajali v mesto v upanju, da bodo tu dobili javna ali zasebna naročila.$^{66}$ Nedvomno je tudi Kobilca v hitro se razvijajoči prestolnici videla priložnost za pridobitev več slikarskih naročil, ki bi ji omogočila daljši obstanek v mestu. Sarajevski javnosti se je predstavila $\mathrm{z}$ razstavitvijo dveh del v dvorani deželnega muzeja, razstavo pa je pospremila objava v lokalnem glasilu Bosnische Post. ${ }^{67}$

K selitvi v Sarajevo je gotovo prispevala tudi mreža poznanstev, ki jih je Kobilca tam imela. Socialna mreža je bila zanjo vedno pomemben dejavnik, tako pri pridobivanju naročil kot tudi pri odločitvah za selitve, in nedvomno je dejstvo, da jev mestu že imela znance, ki so jo tja vabili, pripomogloknjeniodločitvi. ${ }^{68}$

Poleg ohranjenih fresk v semeniški cerkvi, ki so danes v precej slabem stanju, se je v zasebni lasti ohranilo več študij zanje v oljni tehniki. Ohranili sta se študiji glavnih prizorov, Zedinjenje Cerkve in Češčenje Marije, ter upodobitev sv. Helene in neprepoznanega svetnika v tondu. Poleg tega so se ohranile tudi fotografske študije modela za Marijo, za katero je Kobilca v spominih omenila, da je dobila »fin model «. ${ }^{69} \mathrm{Iz}$ slikarkinih spominov je razvidno, da je ikonografski program oblikoval in nadziral nadškof Stadler, ki ni dopuščal odstopanj od načrtovane izbire svetnikov, aktivno pa je bil angažiran tudi pri iskanju modelov in kostumov za upodobitve. ${ }^{70}$ Freski se povsem prilagajata polkrožno zaključenemu arhitekturnemu okvirju in sta kompozicijsko podobno zasnovani s Kristusom oziroma Marijo na oblaku, pod njima pa so v piramidalnih skupinah simetrično na obe strani razporejeni svetniki oziroma cerkveni dostojanstveniki.

Na vzhodni strani proti severu orientirane cerkve je v niši naslikan prizor Češčenja Marije (sl. 3). Na oblaku je upodobljena Marija kraljica z Detetom, obdana z angelskimi glavicami. Pod njo sta stolpasto razporejeni skupini jezuitskih svetnikov, po devet na vsaki strani, tako da zapolnjujeta slikarsko površino. Primerjava s študijo za fresko kaže spremembo v številu svetnikov, prvotno sta bili predvideni skupini $\mathrm{z}$ osmimi svetniki na levi in sedmimi na desni strani, kar je bilo v končni izvedbi spremenjeno v skupini po devet svetnikov, nekoliko pa se je spremenila tudi postavitev figur na levi strani. ${ }^{71}$ Med svetniki je $\mathrm{v}$ levi skupini $\mathrm{v}$ klečeči figuri $\mathrm{v}$ ospredju mogoče prepoznati sv. Ignacija Lojolskega, ${ }^{72}$ odetega v mašni plašč. Ob njem stoji sv. Alojzij Gonzaga ${ }^{73}$ ki je upodobljen kot

64 Mary SPARKS, The Development of Austro-Hungarian Sarajevo, 1878-1918. An Urban History, London 2014, str. 34.

65 SPARKS 2014 (op. 64), str. 77.

66 Gl. Aida LIPA, The Austro-Hungarian Period in Bosnia and Herzegovina. Cultural Politics in Bosnia and Herzegovina and the Creation of the Western Type of Art, Kakanien revisited, 26. 5. 2006, str. 1-26, http://www. kakanien-revisited.at/beitr/fallstudie/Alipa1 (26. 5. 2016).

67 Gemälde Ausstelung 1897 (op. 59), str. 2. O tem priča tudi zapis v časopisu Bosnische Post (Sarajevoer Kunstleben 1897 (op. 59), str. 3), da si namerava umetnica urediti atelje v upanju na daljši obstanek v mestu.

68 Kot že omenjeno, TRDINA 1952 (op. 3) str. 103, omenja sanitetnega svetnika Unterlugauerja. O pomenu socialnega mreženja za Kobilco gl. Urška STRLE, V preseku mobilnosti in socialnih mrež. Biografska skica Ivane Kobilca, Dve domovini, 48, 2018, str. 147-162.

69 VURNIK 1923 (op. 3), str. 109.

70 VURNIK 1923 (op. 3), str. 109.

71 Študija je v zasebni lasti.

72 Friederike WERNER, Ignatius von Loyola, Lexikon der christlichen Ikonographie, 6, Darmstadt 2015, stp. 568-573.

73 Vincent MAYR, Lieselotte SCHÜTZ, Aloysius (Luigi) Gonzaga, Lexikon der christlichen Ikonographie, 5, Darmstadt 2015, stp. 100-101. 


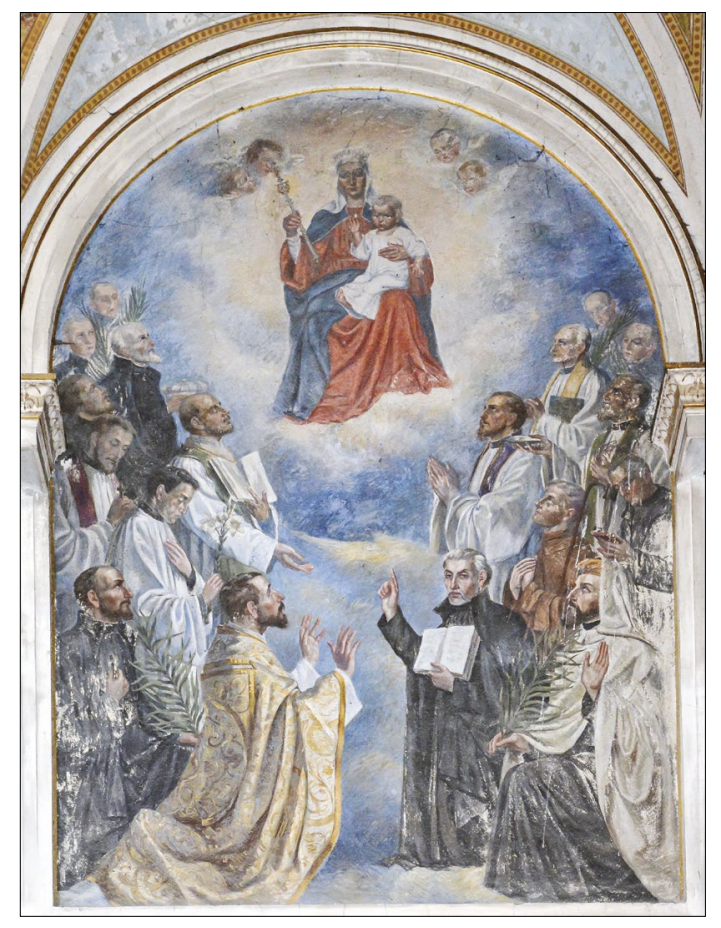

3. Ivana Kobilca: Čě̌čenje Marije, 1898, semeniška cerkev sv. Cirila in Metoda, Sarajevo

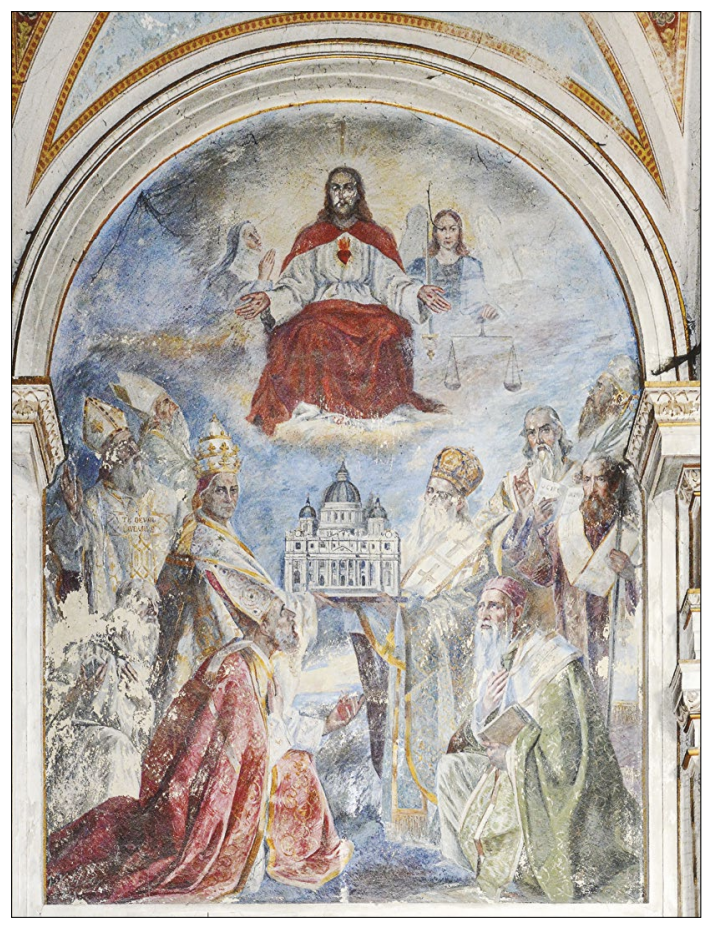

4. Ivana Kobilca: Zedinjenje Cerkve, 1898, semeniška cerkev sv. Cirila in Metoda, Sarajevo

mladenič s sklonjeno glavo in levico na prsih ter lilijo v desnici, na vrhu skupine pa je moč prepoznati še sv. Frančiška Borgio, ${ }^{74}$ ki v rokah drži vojvodski klobuk. V ospredju desne skupine je na kolenu priklonjen jezuitski misijonar in mučenec sv. Janez de Brito. ${ }^{75} \mathrm{~V}$ figuri mladeniča s knjigo v roki ter sklonjeno glavo na robu freske je mogoče prepoznati sv. Janeza Berchmansa. ${ }^{76}$

Vsebinsko zanimivejši je prizor Zedinjenje Cerkve $\mathrm{z}$ izrazito politično propagandno konotacijo na zahodni strani (sl. 4). Na vrhu je na oblaku upodobljen motiv Srca Jezusovega, ki ga obdajata redovnica $v$ priprošnji in nadangel Mihael $z$ mečem in tehtnico. Ivana Kobilca je v spominih omenila, da naj bi naslikala sv. Klaro in Dominika [sic!], ${ }^{77}$ po mnenju Lidije Tavčar pa naj bi šlo za upodobitev motiva Deesis, kjer naj bi bila ob Kristusu Marija [sic!] in nadangel Mihael. ${ }^{78}$ Opredeljevanje ženske figure za Marijo je zaradi redovniškega oblačila docela nesmiselno, zaradi habita, ki spominja na klarise, pa bi svetnico sicer lahko opredelili za sv. Klaro, čeprav gre bolj verjetno za sv. Marjeto Marijo Alakok, pobudnico češčenja Srca Jezusovega. ${ }^{79}$

V spodnjem planu sta upodobljeni skupini cerkvenih odličnikov vzhodne in zahodne cerkve, med katerimi izstopata papež in patriarh carigrajske cerkve, ki skupaj držita v rokah model vatikanske

74 Theodor KURRUS, Franz Borgia (de Borja), Lexikon der christlichen Ikonographie, 6, Darmstadt 2015, stp. 315-317.

75 Ludwig KOCH, Britto, Jesuiten-Lexikon. Die Gesellschaft Jesu einst und jetzt, Paderborn 1934, stp. 265-266.

76 Frans MOLLE, Johannes Berchmans, Lexikon der christlichen Ikonographie, 7, Darmstadt 2015, stp. 85-86.

77 VURNIK 1923 (op. 3), str. 109.

78 Lidija TAVČAR, Videla sem svet in življenje. Ob 90. obletnici smrti Ivane Kobilca (1861-1926), Podbrezje 2016, str. 66.

79 Lieselotte SCHÜTZ, Margareta Maria Alacoque, Lexikon der christlichen Ikonographie, 7, Darmstadt 2015, stp. 505; Albert WALZER, Herz Jesu, Lexikon der christlichen Ikonographie, 2, Darmstadt 2015, stp. 250-254. 
bazilike sv. Petra. Papeža na levi strani obdajajo štirje cerkveni očetje zahodne cerkve. Na vrhu se proti Kristusu obrača sv. Gregor Veliki, za njim je z napisom TE DEUM LAUDAMUS na prsih zaznamovan sv. Ambrož, pod njim se priklanja sv. Hieronim, pred katerim kleči sv. Avguštin. Zamenjava papeške tiare z mitro pri Gregorju Velikem je verjetno namenjena razlikovanju od upodobljenega papeža, ki drži model cerkve. V skupini mož za carigrajskim patriarhom, ki mu je bila podrejena pravoslavna skupnost v Bosni, stojijo sv. Bazilij Veliki na vrhu, sv. Atanazij Veliki z odprto knjigo pred njim, sv. Janez Krizostom (Zlatoust) pod obema ter sv. Gregor Nazianški na kolenih ob patriarhu. Pogled papeža, ki drži cerkev, je obrnjen v gledalca in da misliti, da gre za točno določenega papeža. Glede na motiv Zedinjenja Cerkve bi v njem lahko iskali podobo Leona XIII., aktualnega papeža v času nastanka fresk, čeprav obraz nima njegovih portretnih karakteristik. Papež Leon XIII. je namreč leta 1894 z encikliko Preclara gratulationis publicae ${ }^{80}$ pozval k združitvi vzhodne in zahodne cerkve ${ }^{81}$ Nasproti njega je najverjetneje upodobljen carigrajski patriarh Antim VII. (1835-1913, patriarh 1895-1896).

Ob upodobitvi motiva Zedinjenja Cerkve je treba podati tudi kontekst nastanka freske in njen politični pomen. Že Kobilca je upodobitev opisala kot prizor, ki je pozneje tak prah dvignil«. ${ }^{82}$ in vpogled $\mathrm{v}$ cerkveno in politično dogajanje $\mathrm{v}$ času nastanka fresk pojasni njeno izjavo. Okupacija Bosne in Hercegovine je za Sveti sedež pomenila prvi korak k uveljavitvi katolištva v večkonfesionalni deželi, saj je bila ob začetku okupacije rimskokatoliška veroizpoved po zastopanosti šele na tretjem mestu, za najštevilčnejšo srbsko pravoslavno skupnostjo, podrejeno carigrajskemu patriarhu, in islamsko skupnostjo.$^{83} \mathrm{Ob}$ koncu osmanske vladavine sta si tako Srbska pravoslavna kot tudi Katoliška cerkev prizadevali pridobiti muslimane na svojo stran. ${ }^{84}$ Tak pristop ni ustrezal avstroogrski oblasti, ki se je pod vodstvom avstroogrskega finančnega ministra in guvernerja Bosne in Hercegovine Benjamina von Kállaya (1839-1903) zavzemala za ohranitev muslimanske skupnosti, tj. Bošnjakov, kot samostojne nacionalne identitete, poleg Hrvatov in Srbov. ${ }^{85}$ Oblast je pričakovala, da se bo Katoliška cerkev podredila dolgoročnim interesom monarhije, in jo je poskušala restriktivno regulirati. ${ }^{86}$ Drugače kot avstroogrska oblast, ki je želela ohraniti muslimansko skupnost kot samostojno entiteto, sta si tako Katoliška kot tudi Pravoslavna cerkev prizadevali pridobiti muslimansko prebivalstvo na svojo stran, kar je vodilo tako do konfliktov z oblastjo kot tudi medsebojnih sporov in še poslabševalo že tako napeti odnos. ${ }^{87}$

Po drugi strani si je Katoliška cerkev v tem času aktivno prizadevala za zedinjenje Cerkve. Ekumenizem oz. prizadevanje za spravo, sodelovanje, zbližanje in enotnost krščanskih cerkva ${ }^{88}$ v obravnavanem kontekstu pomeni ožjo idejo združitve vzhodne in zahodne cerkve, ki je zaznamovala pontifikat papeža Leona XIII. Zanimanje za idejo združitve vzhodne in zahodne Cerkve

80 Dokument je v angleškem prevodu dostopen na: http://www.papalencyclicals.net/Leo13/113praec.htm (10. 10. 2020).

81 GRIJAK 2001 (op. 8), str. 262.

82 VURNIK 1923 (op. 3), str. 109.

83 ĐAJA 1994 (op. 8), str. 39.

84 GOTTSMANN 2010 (op. 11), str. 87-88.

85 Zoran GRIJAK, Predstavka episkopata vrhbosanske metropolije iz 1903. godine u svjetlu austougarske vjerske politike u Bosni i Hercegovini, Croatica christiana periodica, 32/62, 2008, str. 77.

86 Restrikcije so se nanašale na področje konverzij muslimanov in pravoslavcev v katoliško vero, gl. Zlatko KUDELIĆ, Vjerske konverzije u Bosni i Hercegovini s kraja 19. i početkom 20. stoljeća u svjetlu nepoznatog arhivskog gradiva, Croatica christiana periodica, 35/68, 2011, str. 87-111.

87 GRIJAK 2008 (op. 85), str. 84-85.

88 Ekumenizem, Splošni religijski leksikon (ur. Adalbert Rebić), Ljubljana 2007, str. 295. 
je najti že pri njegovem predhodniku, Piju IX. (1792-1878, papež od 1846), ki je v času svojega pontifikata pravoslavnim vernikom poslal dve pismi, v katerih jih je pozval k zedinjenju s "pravo" Cerkvijo, pri Leonu XIII. pa je vprašanje zedinjenja Cerkve postalo ena glavnih točk njegovega programa, v katerem se je zavzemal zlasti za povezavo Pravoslavne cerkve na Balkanu s Katoliško cerkvijo. ${ }^{89} \mathrm{Za}$ dosego tega cilja se je naslonil na dediščino sv. Cirila in Metoda, ${ }^{90}$ slovanskih apostolov, ki sta pri svojem misijonarskem delu širila slovansko liturgijo in bila obenem podpornika papeža, in leta 1880 razširil praznovanje njunega godu na celotno Cerkev ter pozval k združenju vzhodnih cerkva s Katoliško cerkvijo. Do neposrednega poziva k zedinjenju pravoslavnih slovanskih narodov s Katoliško cerkvijo je prišlo z apostolskim pismom leta 1894, istega leta pa je papež tudi imenoval Stadlerja za apostolskega delegata za zedinjenje cerkva. ${ }^{11}$

Stadler je prevod papeževega apostolskega pisma poslal pravoslavnim cerkvenim dostojanstvenikom v Bosni in Hercegovini in predstavil načela, potrebna za doseganje zedinjenja cerkva. $\mathrm{V}$ njih je izpostavil nujnost preseganja nacionalne pripadnosti vernikov, ki se je nikakor ne sme identificirati $z$ versko pripadnostjo, ter predlagal srečanje katoliških in pravoslavnih strokovnjakov, ki bi skupaj skušali ugotoviti, kakšno Cerkev je Jezus ustanovil..$^{92}$ Pravoslavne metropolite je prosil za mnenje in predlagal srečanje. ${ }^{93}$ Tako papeževo apostolsko pismo kot tudi Stadlerjev poziv pravoslavnim metropolitom nista bila uspešna. Stadler ni od pravoslavnih metropolitov dobil niti odgovora, papež pa je leta 1895 dobil javni odgovor carigrajskega patriarha Antima VII. in drugih patriarhov sinode, $\mathrm{v}$ katerem so odločno zavrnili katoliške pozive $\mathrm{k}$ zedinjenju in odbili cerkveni nauk Katoliške cerkve kot povsem zgrešen. Po njihovem mnenju bi bilo zedinjenje mogoče samo na osnovi pravoslavja. ${ }^{44}$ Kot odgovor na pravoslavno zavrnitev je papež leta 1896 z encikliko Satis Cognitum $^{95}$ še odločneje zavzel stališče, da je prava Cerkev samo ena in pravi škof samo rimski kot naslednik sv. Petra, ter ponovno pozval k vrnitvi pravoslavcev v enotno Katoliško cerkev, saj naj bi dogmatske razlike ne predstavljale prepreke zedinjenju. ${ }^{96}$

Ne samo apostolsko pismo, tudi Stadlerjevo imenovanje za apostolskega delegata za zedinjenje Cerkva je dvignilo precej prahu, tako pri carigrajskem patriarhu kot tudi pri avstroogrski oblasti. $\mathrm{Ob}$ imenovanju namreč ni bilo eksplicitno navedeno, ali gre za pooblastila na področju Bosne in Hercegovine ali širše, za vse balkanske pravoslavne države, kar je vznemirilo obe strani. Carigrajski

89 Tomo VUKŠIĆ, Katoličanstvo i pravoslavlje na prijelazu iz 19. u 20. stoljeće, Crkva u svijetu, 36/3, 2001, str. 285-286. Čeprav je papež v svojih načrtih združevanja Pravoslavne s Katoliško cerkvijo sprva videl tudi Rusijo, se je v danih političnih razmerah zavedal nevarnosti ruskega povezovanja z balkanskimi pravoslavnimi narodi, kar bi ogrozilo tako Avstro-Ogrsko kot tudi položaj južnoslovanskih katolikov; gl. GRIJAK 2001 (op. 8), str. 60, 69.

90 Josef MYSLIVEC, Cyrillus (Konstantin) und Methodius, Lexikon der christlichen Ikonographie, 6, Darmstadt 2015, str. 23.

91 VUKŠIĆ 2001 (op. 89), str. 286-287; GRIJAK 2001 (op. 8), str. 257, 263.

92 Stadlerjeva štiri načela so zajemala: zedinjenost po Duhu v molitvi, preseganje nacionalne pripadnosti, ki se je ne sme enačiti z versko, ločevanje pomembnih stvari od nepomembnih ter srečanje strokovnjakov obeh strani, ki bi skupaj skušali odgovoriti na vprašanje, kakšno Cerkev je Jezus ustanovil in kakšni so njeni prepoznavni elementi. Prim. Tomo VUKŠIĆ, Pregled katoličke i hrvatske periodike u BiH od 1878. do 1918. s posebnim osvrtom na časopis Balkan, Hum. Časopis Filozofskog fakulteta Sveučilišta u Mostaru, 2, 2007, str. 93.

93 VUKŠIĆ 2007 (op. 92), str. 93.

94 GRIJAK 2001 (op. 8), str. 263-264.

95 Enciklika je v angleščini dostopna na: http://www.vatican.va/content/leo-xiii/en/encyclicals/documents/hf_lxiii_enc_29061896_satis-cognitum.html (31.10.2020).

96 Priznavanje papeža kot vrhovne oblasti je ena od ključnih dogmatskih razlik med Katoliško in Pravoslavno cerkvijo; prim. GRIJAK 2001 (op. 8), str. 258, 268. 
patriarh Antim VII. je nameraval s podporo ruske strani z ukrepi onemogočiti Stadlerjevo pridobivanje pravoslavnih cerkvenih dostojanstvenikov na Balkanu za cerkveno unijo, avstroogrska oblast, ki je videla nevarnost, da bi Stadler tako postal najvplivnejša oseba v monarhiji na področju cerkvenega zedinjenja, pa je pozorno spremljala njegovo delovanje na tem področju. ${ }^{97}$

Kljub ostri zavrnitvi in nenaklonjenemu razpoloženju Pravoslavne cerkve je Stadler nadaljeval svoje delo. S svojimi načrti je seznanil zagrebškega nadškofa Josipa Juraja Posilovića (1834-1914, nadškof od 1894) v pismu, v katerem je poudarjal nujnost poznavanja skupne dediščine, tj. da bi se katoliški duhovniki morali spoznati tudi z vzhodnim obredom in staroslovanskim liturgičnim koledarjem, zato je nameraval v katoliško bogoslovje uvesti kompendij pravoslavne liturgije. Njegovi načrti so predvidevali tudi ustanovitev odborov, ki bi prebivalstvu približali idejo zedinjenja Cerkve, in ustanovitev časopisa Balkan, ki bi bil v pomirljivem, nekonfliktnem tonu tematsko osredotočen na vzhodno liturgijo in cerkveno pravo in bi se izogibal kakršni koli polemičnosti. ${ }^{98}$ Zanimivo je tudi, da je Stadler, ki je pri svojem teoretičnem raziskovanju ekumenizma Pravoslavno cerkev zaradi dogmatskih razlik imenoval heretično, $\mathrm{v}$ praktičnem delovanju svoje stališče precej ublažil in pravoslavnih vernikov ni obravnaval kot heretike, temveč se je nanje obračal kot na »brate, od nas ločene v veri«. ${ }^{99}$

Kot del tega programa, čeprav ne strogo gledano v sklopu vrhbosenske nadškofije, je treba izpostaviti tudi pobudo za uvedbo glagoljaške liturgije v hrvaške škofije, katere podpisnik je bil poleg hrvaških škofov tudi Stadler. Uvajanje stare cerkvene slovanščine kot liturgičnega jezika je predstavljalo enega od korakov na poti zedinjenja, za katero se je Stadler zavzemal v svojem programu, a je bila pobuda $\mathrm{z}$ dvema dekretoma leta 1898 in nato še 1902 zavrnjena. Drugi tak poskus pa je bila ustanovitev hrvaškega zavoda $\mathrm{v}$ Rimu, $\mathrm{v}$ katerem bi poučevali tako katoliški kot tudi pravoslavni nauk, duhovniki pa bi spoznali tudi staroslovanski jezik in liturgijo. Collegium Hieronymianum pro Croatica Gente je bil leta 1901 sicer ustanovljen, a v ustanovitveni buli ni bilo opredelitve zavoda kot središča za promocijo edinosti, leto po ustanovitvi pa je bilo iz uradnega naziva zavoda izbrisano tudi hrvaško ime. ${ }^{100}$

Malo uspeha je bilo tudi z leta 1896 ustanovljenim časopisom Balkan. Že pri izbiri urednika je Stadler naletel na težave, saj pomirljivi ton časopisa nekaterim teologom na hrvaški strani ni ustrezal. Stadlerjevi poskusi, da bi prek Balkana ustvaril dialog med pravoslavno in katoliško skupnostjo, so bili neuspešni. Odziv pravoslavne strani na časopis, ki je z namenom približanja pravoslavcem izhajal tudi v cirilici, je bil prezirljiv in porogljiv. Čeprav so bili tudi pravoslavni teologi povabljeni k sodelovanju, so zavračali vsak stik tako s časopisom kot tudi $\mathrm{z}$ apostolskim delegatom, časnik pa je izzval tudi ostre odzive v pravoslavnem tisku, kjer so ga imenovali »glasilo rimskega papeštva« in »novo sredstvo stare borbe Rima«. ${ }^{101}$ Prav v času nastajanja Kobilčinih fresk, v začetku leta 1898, je sarajevski pravoslavni metropolit Nikolaj Mandić (1840-1907, metropolit od 1896) Balkan označil za »sredstvo katoliške propagande« in prepovedal vsem pravoslavnim duhovnikom in

97 GRIJAK 2001 (op. 8), str. 272. Dejansko je šlo za podelitev pooblastil na področju Bosne in Hercegovine, kar se je razjasnilo leta 1896. Avtor hkrati opozarja, da je bilo pooblastilo verjetno mišljeno širše, a je bilo zaradi avstroogrskih političnih pritiskov naknadno omejeno na področje Bosne in Hercegovine.

98 Niko IKIĆ, Stadlerova upornost u promicanju jedinstva. Stadlerova skica jedinstva u povodu 100. obljetnice njegove smrti, Služba Božja. Liturgijsko-pastoralna revija, 59/2, 2019, str. 130.

99 GRIJAK 2001 (op. 8), str. 257-258.

100 Tomo VUKŠIĆ, Josip Stadler - »jedinstvu i bratskoj slogi«, Crkva u svijetu, 27/4, 1992, str. 231-232.

101 VUKŠIĆ 2007 (op. 92), str. 105-106. 
vernikom vsak stik z njim. ${ }^{102}$ Leta 1902 je časopis prenehal izhajati zaradi zaostrenih političnih razmer, ko je bil v glasilu Srbobran objavljen članek Hrvati i Srbi, ki je pozval Srbe v boj proti Hrvatom do istrage (sl. iztrebljenja) in sprožil burne demonstracije v Zagrebu. V takšnih sovražnih razmerah pozivanje $\mathrm{k}$ slogi in cerkvenemu zedinjenju ni imelo več smisla, hkrati s časopisom Balkan pa je zamrl tudi Stadlerjev ekumenski program. ${ }^{103}$

Kot je pokazala zgodovina, zedinjenju Cerkve v Bosni in Hercegovini prostor in čas nista bila naklonjena, zato toliko bolj preseneča papeževa in posledično tudi Stadlerjeva vztrajnost. Odnos pravoslavne strani do razprav s Katoliško cerkvijo v devetdesetih letih 19. stoletja je bil enako odbijajoč kot desetletje prej in nič ni kazalo na kakršno koli zbliževanje, zato preseneča papežev pretirani optimizem glede možnosti zedinjenja. Vzrok gre pripisati osebam, ki so papeža obveščale o razpoloženju Pravoslavne cerkve in njenih dostojanstvenikov. Te so bile prežete z idealiziranimi pogledi na zedinjenje in so pri tem prezrle dejansko nenaklonjenost pravoslavne strani. Med njimi je bil tudi Strossmayer, ki je v verski enotnosti videl izhodišče za zedinjenje južnih Slovanov, odraz njegove vizije pa je viden tudi na freskah v đakovski katedrali. ${ }^{104}$ Strossmayerjevo navdušenje za zedinjenje Cerkve se je začelo že v študentskem obdobju, poseben pomen pa je imel tudi kult sv. Cirila in Metoda, ki je zanj predstavljal ne samo jedro cerkvene enotnosti za slovanske narode, ampak se je čutil z njim tudi osebno povezanega: sv. Metod je leta 870 postal škof panonsko-sirmijske škofije in Strossmayer se je kot sremski škof imel za njegovega naslednika. ${ }^{105}$ Strossmayer se je že zgodaj začel zavzemati za oživljanje stare cerkvene slovanščine, Hrvaški, ki je edina vsaj delno ohranila izvorno ciril-metodovsko dediščino glagolice, pa je zato namenil posebno vlogo pri združevanju vseh Slovanov v zedinjeni Cerkvi. ${ }^{106}$ Zedinjenje Cerkve je bilo za Strossmayerja pomembno vprašanje in obsežna korespondenca priča o njegovi vpletenosti v oblikovanje papeževih stališč, čeprav ne vedno $\mathrm{z}$ uspešnim rezultatom. ${ }^{107}$

$\mathrm{V}$ đakovski katedrali so na freskah $\mathrm{v}$ polkupolah apsid transepta in $\mathrm{v}$ apsidi prezbiterija trije biblijski prizori, obarvani s politično-nacionalnimi elementi, ki pričajo o Strossmayerjevih nazorih. Še najbolj nevtralen je prizor Objokovanja Kristusa v severni apsidi transepta, ki z vključitvijo sv. Cirila in Metoda ter drugih slovanskih svetnikov opozarja na krščansko preteklost Slovanov. Zanimivejša sta preostala prizora. V južni apsidi transepta je naslikan Poklon pastirjev in Svetih treh kraljev (Ludwig Seitz, 1878), kjer upodobljeni pastirji nosijo noše različnih jugoslovanskih narodov (sl. 5). Mariji z Detetom se poklanjajo Hrvat, ki prinaša grozdje, Slavonka z žitom, Dalmatinka z oljčno vejico s plodovi, Bolgar s košaro sadja na ramenu in Srb, ki zganja skupaj ovce. ${ }^{108}$ Freska je nastala kot odraz tedanjega političnega dogajanja, ki je nakazovalo propad osmanskega imperija

102 Tomo VUKŠIĆ, Nadbiskup Josip Stadler (1881.-1918.) i Srbi, Crkva u svijetu, 34/1, 1999, str. 58.

${ }^{103}$ Poleg političnih okoliščin je k prenehanju izhajanja prispevalo tudi dejstvo, da so za časopis vedno težje našli sodelavce; gl. GRIJAK 2001 (op. 8), str. 277.

${ }^{104}$ Dragan DAMJANOVIĆ, Nacionalne ideologije i umjetnost u 19. stoljeću na primjeru fresaka u apsidama đakovačke katedrale, Društvena istraživanja, 18/3, 2009, str. 461.

105 Andrija ŠULJAK, Biskup Josip Juraj Strossmayer i ćirilometodsko-glagoljska baština, Diacovensia, 2/1, 1994, str. 282.

106 ŠULJAK 1994 (op. 105), str. 282-283.

${ }^{107}$ Precej manj je bila stari cerkveni slovanščini v liturgiji naklonjena avstroogrska oblast, ki je v emancipaciji Slovanov in rasti panslavizma videla nevarnost krepitve moči slovanskih narodov znotraj monarhije. Tako je na primer oblast prepovedala mašo v stari cerkveni slovanščini ob posvetitvi đakovske katedrale. Gl. ŠULJAK 1994 (op. 105), str. 268.

108 DAMJANOVIĆ 2009 (op. 26), str. 463-465. 


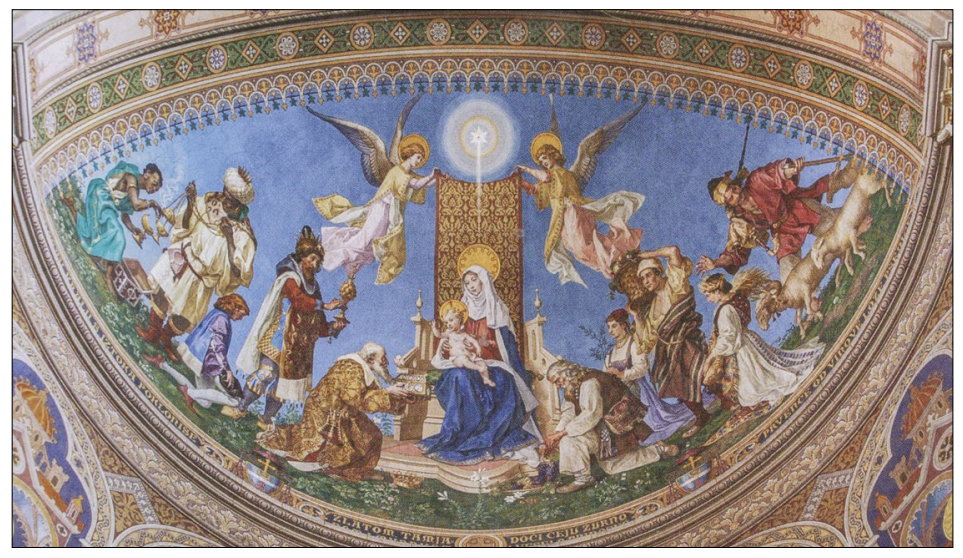

5. Ludwig Seitz:

Poklon kraljev in pastirjev, 1878, stolna cerkev sv. Petra, Đakovo

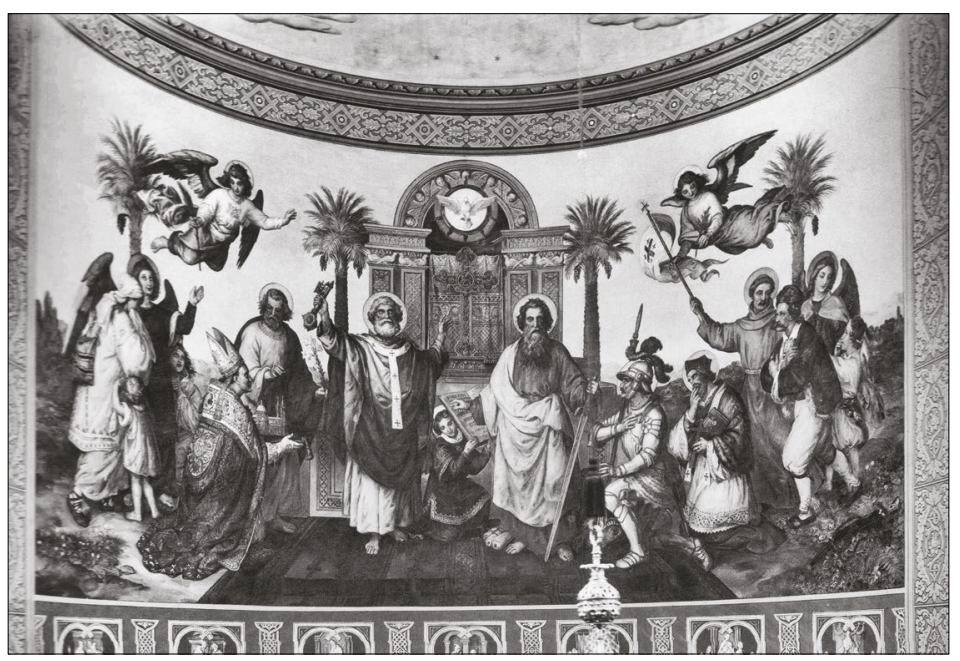

6. Alexander Maximilian Seitz:

Prestol sv. Petra, 1880,

stolna cerkev sv. Petra, Đakovo

na Balkanu in osvoboditev južnih Slovanov. ${ }^{109}$ Strossmayerjeva vizija glede mogočega povezovanja južnoslovanskih narodov se je skozi čas sicer spreminjala, a vselej ohranja vodilno vlogo Hrvatov v južnoslovanskem združevanju, na kar nakazuje upodobitev Hrvata, ki se prvi priklanja Jezusu. ${ }^{110}$

Za obravnavano temo najzanimivejša je freska v apsidi prezbiterija, delo Alexandra Seitza iz leta 1879. V apsidalni konhi je naslikano Marijino kronanje, $\mathrm{v}$ pasu pod njo pa je $\mathrm{v}$ sredini naslikan prestol sv. Petra, pred katerim stojita sv. Peter in sv. Pavel (sl. 6). Ob sv. Petru kleči Strossmayer, ki mu izroča model cerkve, poleg njega pa stoji sv. Jožef. V jukstapoziciji sta upodobljena sv. Jurij in sv. Janez Nepomuk, na skrajnem robu pa sta dve skupini figur: $z$ leve strani vodi angel proti prestolu sv. Petra »krščansko Bošnjakinjo« (tj. pravoslavko) z otrokoma, z desne pa kaže »Bošnjaku mohamedamcu" pot proti prestolu sv. Janez Kapistran. Sv. Jožef in sv. Jurij sta Strossmayerjeva zavetnika, sv. Janez Nepomuk zavetnik spovedi, sv. Janez Kapistran pa kot frančiškan predstavlja čuvaja katoliške vere in hkrati kot svetnik bojevnik simbolizira stoletno vojno z Osmanskim

\footnotetext{
${ }^{109}$ Gre za balkansko krizo (vstajo v Bosni in Hercegovini, Bolgariji ter rusko-turško vojno), ki je prinesla velike spremembe meja ter političnega statusa posameznih narodov. Prim. STAVRIJANOS 2005 (op. 10), str. 375-393.

${ }^{110}$ DAMJANOVIĆ 2009 (op. 26), str. 468.
} 


\section{Oton Iveković:}

Sv. Ciril in Metod pri moravskem knezu Rastislavu, 1898, semeniška cerkev sv. Cirila in Metoda, Sarajevo
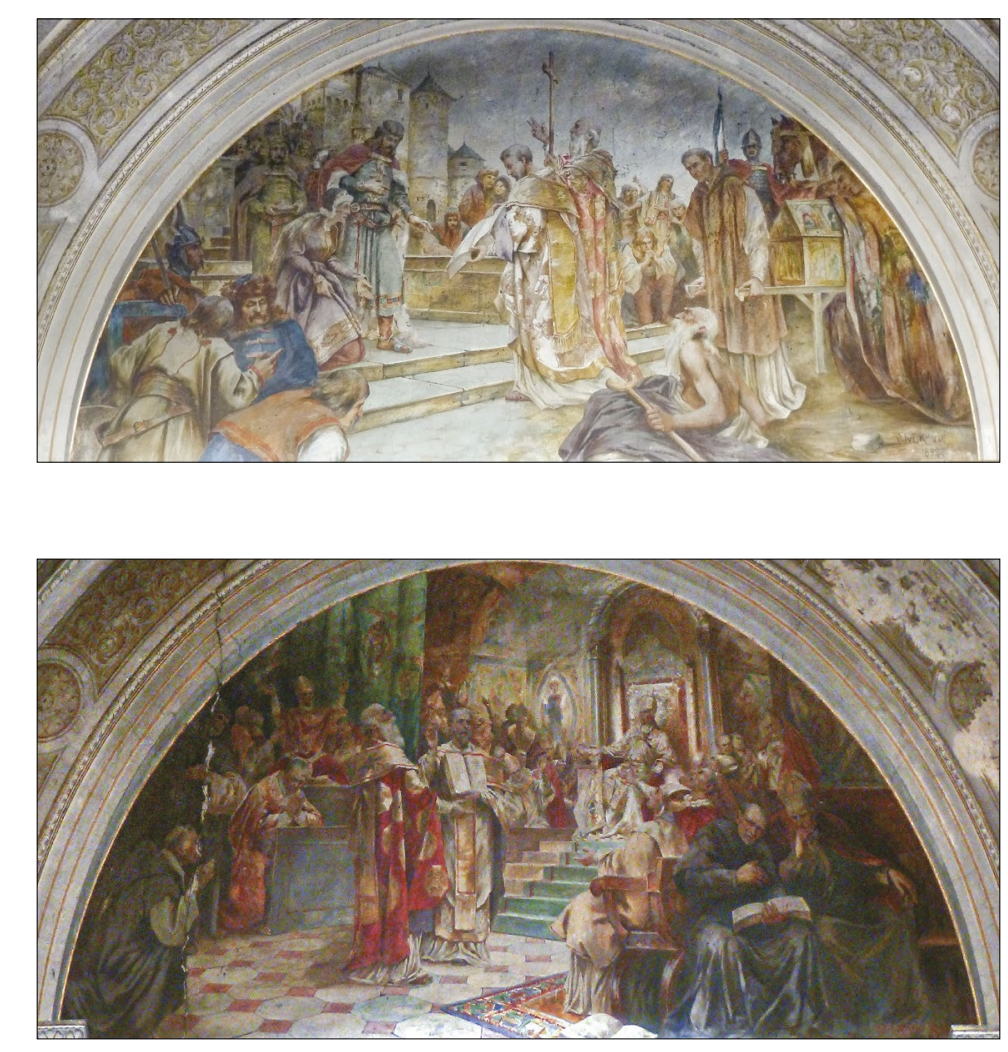

8. Oton Iveković:

Sv. Ciril in Metod pred papežem

Hadrijanom II., 1898,

semeniška cerkev sv. Cirila

in Metoda, Sarajevo

cesarstvom in islamom, ki se je v veliki meri odvijala na ozemlju đakovske škofije. ${ }^{111} \mathrm{Na}$ tej freski sta jasno izražena Strossmayerjev nazor, da je edinost kristjanov mogoča samo prek papeškega primata, in njegov up, da se bo islamizirano prebivalstvo Bosne in Hercegovine po odhodu turške oblasti vrnilo v krščanstvo. Na freski sta hkrati poudarjena tudi škofova zgodovinska pravica do bosenske škofije (đakovska škofija je bila prvotno ustanovljena kot bosenska škofija) in upanje, da mu bo novoustanovljena bosenska škofija dana v upravljanje. ${ }^{112}$

Đakovske freske lahko primerjamo s sarajevskimi freskami, saj imajo kljub časovni distanci dvajsetih let nekaj podobnosti. Tako freske v semeniški cerkvi kot tudi v đakovski katedrali poudarjajo vlogo sv. Cirila in Metoda kot povezovalcev slovanskih narodov. V semeniški cerkvi, ki jima je tudi posvečena, sta upodobljena ključna prizora njunega misijonskega delovanja, prihod k moravskemu knezu Rastislavu ter zagovarjanje staroslovanske liturgije pred papežem (sl. 7-8), medtem ko sta na đakovski freski upodobljena med drugimi slovanskimi svetniki. ${ }^{113}$ Za glavni oltar đakovske katedrale je bila prvotno namenjena slika Sv. Ciril in Metod pred papežem Hadrijanom, delo Nicole Consonija (1814-1884), a na koncu ni bila vključena v opremo katedrale. ${ }^{114} \mathrm{~V}$ obeh

${ }^{111}$ Sv. Janez Kapistran je leta 1456 vodil krščanske čete v boj proti Turkom in obranil Beograd turške nevarnosti; gl. Anđelko MIJATOVIĆ, Ivan Kapistran i borbe za Beograd 1456. godine, Croatica christiana periodica, 11/19, 1987, str. 156-164.

112 DAMJANOVIĆ 2009 (op. 26), str. 363-364.

${ }^{113}$ Freski s prizoroma iz življenja sv. Cirila in Metoda v semeniški cerkvi sta opremljeni z napisi.

${ }^{114}$ Slika je nato prišla $\mathrm{v}$ fond Jugoslovanske (sedaj Hrvaške) akademije znanosti in umetnosti v Zagrebu; prim. Borivoj POPOVČAK, Portreti Josipa Jurja Strossmayera. Izložba u povodu 130. obljetnice osnutka Strossmayerove galerije, Hrvatska akademija znanosti i umjetnosti, Zagreb 2014, str. 37-38. 
skupinah fresk je tudi izraženo, da je zedinjenje Cerkve mogoče samo pod papeškim primatom: $\mathrm{v}$ đakovskih freskah o tem priča upodobitev prestola sv. Petra, h kateremu se bližajo pravoslavna vernica s svojimi otroki in musliman, na semeniški freski pa je to razvidno iz modela cerkve, $t \mathrm{j}$. vatikanske bazilike, ki jo držita papež in carigrajski patriarh. Po drugi strani pa je v sarajevski freski povsem odsotna kakršna koli nacionalna vsebina, ki prežema đakovske freske. Stadler se je nedvomno zavedal občutljivosti teme, saj se ji je že v svojem programu izognil.

Kljub vsemu trudu je Stadlerjev ekumenski program doživel velik poraz in Kobilčina freska, ki je bila zasnovana kot vizualna reprezentacija Stadlerjevih političnih ciljev, danes predstavlja skromen, a pomemben spomin na nadškofove neizpolnjene ekumenske načrte. ${ }^{115}$

${ }^{115}$ Prispevek je nastal v okviru projekta Likovna umetnost med cenzuro in propagando od srednjega veka do konca prve svetovne vojne (L7-8282), ki ga sofinancirata Javna agencija za raziskovalno dejavnost Republike Slovenije in Slovenska akademija znanosti in umetnosti. 


\title{
Visual Propaganda of Stadler's Ecumenic Project in Frescoes by Ivana Kobilca
}

\author{
Summary
}

The construction of the seminary Church of Sts Cyril and Methodius in Sarajevo was part of the project of the reorganization of Catholic hierarchy by means of which the Roman curia wanted to secure its position in occupied Bosnia and Herzegovina. First, the cathedral of the Sacred Heart was built under the leadership of Archbishop Dr. Josip Stadler between 1884 and 1889, in the years 1893-1896 the construction of the provincial seminary and seminary church followed. Stadler, who was named as the apostolic delegate for unification with the Orthodox church in 1895, consecrated the church and dedicated it to the holy brothers Cyril and Methodius on $8^{\text {th }}$ September 1896. At the time of the consecration, the church was furnished only with the high altar and two side altars, while the painting of the church began only in 1897 and was entrusted to Croatian painter Oton Iveković (1869-1939) and Slovene painter Ivana Kobilca (1861-1926). For Kobilca, who moved to Sarajevo in May 1897, this was one of the first commissions in the Bosnian capital. This raises a legitimate question, which is what the main reason for her coming to the city was. The corrected dating of the frescoes, which were originally dated ca. 1900, that is the time when she had fully settled down in the town, opens up the possibility that the commission for the painting of the Church of Sts Cyril and Methodius was central for her arrival in the town.

The painting of the frescoes of the seminary church was divided into two parts of comparable size between the two painters. In the tambour, Ivekovic painted eight scenes from the life of Christ, in the pendentives of the dome he painted the evangelists, and in the lunettes on each side of the crossing a monumental fresco with a scene from the life of Cyril and Methodius. Ivana Kobilca, for her part, painted the dome. Using Michelangelo's Creation of the Earth as a model, she painted God the Father on the inside of the dome, on the walls of the organ loft and the side galleries she painted four tondi with busts of the saints, and in the semi-circularly enclosed areas above the side altars the scenes Unification of the Church and Veneration of Mary (with Jesuit saints). It is evident from the painter's memoirs that the iconographic programme was designed and overseen by Archbishop Stadler and that he did not allow any deviation from the planned depiction of the saints, which attests to how important the painting was for the archbishop.

Painted on the northern wall of the right transept wing is the scene of the Veneration of Mary where the Queen of Heaven with Child is accompanied by Jesuit saints, among whom it is possible to identify St Ignatius of Loyola, St Aloysius of Gonzaga, St John de Britto, St Francis Borgia, and St John Berchmans. From a contextual point of view, the scene of the Unification of the Church in the left transept wing is more interesting and has a distinct politically propagandist connotation. Depicted on the cloud, at the top of the painting, is the Sacred Heart, surrounded by a nun (probably St Margaret Mary Alacoque) in an intercession, and archangel Michael with a sword and the scales. Depicted in the lower part are groups of church dignitaries from the Eastern and Western Churches, among whom the pope and the patriarch of the Constantinople church, who hold together in their hands the model of the Vatican basilica of St Peter, stand out. On the left the pope is surrounded by four church fathers of the Western Church, while the patriarch of Constantinople, to whom the Orthodox community in Bosnia was subordinate, is surrounded by four church fathers of the Eastern Church. We can assume that the pope depicted represents Leo XIII (1878-1903), the actual pope at the time the frescoes were made, even though the face of the person depicted has none of Leo XIII's physical characteristics. In 1894 the latter called for the union of the Eastern and Western churches, and a year later he named Josip Stadler as the apostolic delegate for unification with the Orthodox church in the area of the Sarajevo archdiocese. 
This ecumenical work was not an easy task in the prevailing tense political circumstances, where the Catholic and Orthodox Churches strove to win the Muslim community over to their side and the AustroHungarian government obstructed this rapprochement, promoting 'Bosniakism' in an attempt to keep the Muslim population as a separate entity. Stadler's attempts to use the Balkan newspaper to create a dialogue between the Orthodox and Catholic communities were unsuccessful, and precisely at the time these frescoes were created, Stadler suffered a stern rejection by the Sarajevo Orthodox Metropolit Nikolaj Mandić, who in 1898 even issued a circular prohibiting priests and worshippers from having any contact with the new newspaper. The tense relations deteriorated up to 1902, when not only the Balkan newspaper ceased to exist, but also the ecumenical idea. The idea of unifying the Church in Bosnia and Herzegovina suffered a great defeat and today, Kobilca's fresco, designed as a visual representation of Stadler' s political goals, represents only a memory of the archbishop's unsuccessful ecumenical project. 


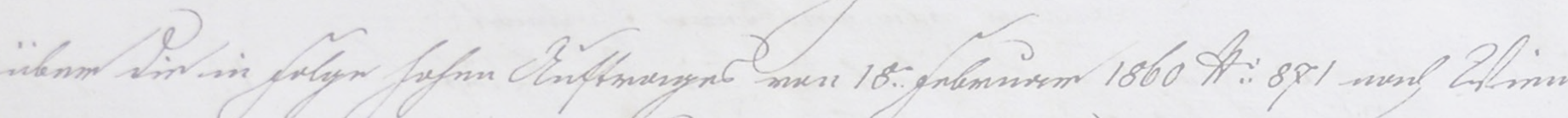

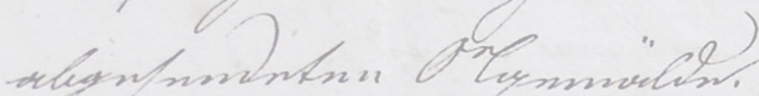

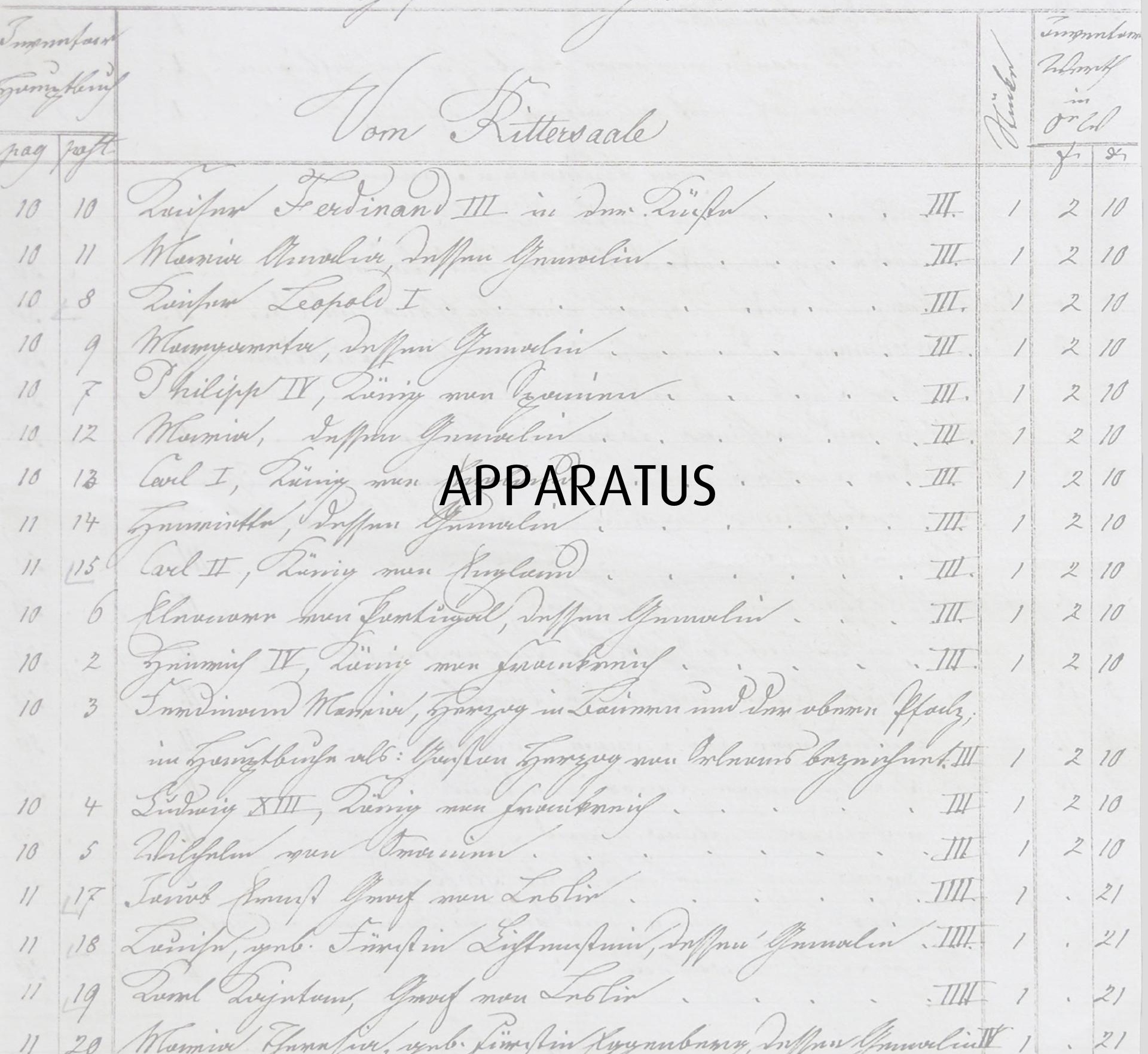

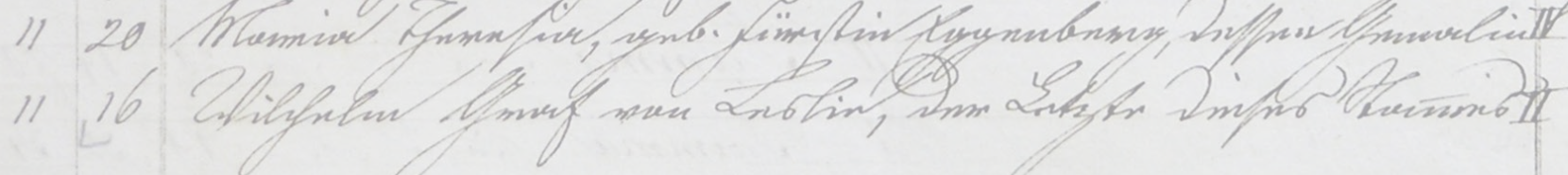




\section{IZVLEČKI IN KLJUČNE BESEDE} Abstracts AND KeYWORDS

\section{Janez Balažic \\ Fragmentarno ohranjene gotske stenske poslikave na zahodnem panonskem robu}

1.01 Izvirni znanstveni članek

Avtor v prispevku obravnava fragmentarno ohranjene stenske poslikave, pripisane regionalnim slikarskim delavnicam, ki so zarisovale t. i. navpično vplivno os po zahodnem panonskem robu. Zbrani primeri navkljub okrnjeni predstavnosti pomembno dopolnjujejo umetnostnozgodovinsko podobo umetnostne produkcije tega prostora v času Luksemburžanov. Prispevek kaže na tvorne povezave med pokrovitelji in umetnostnimi delavnicami. Njihovo produkcijo pred sredino 14. stoletja zaznamuje izzvenevanje visokogotskega linearnega stila, zatem pa ob italijanskih trečentističnih spodbudah "mešani« ali "prehodni« slog tretje in zadnje četrtine 14. stoletja, na vrhuncu češko-dunajske produkcije okoli leta 1400 pa tudi tu zmaga mednarodni gotski slog, ki odzvanja še globoko v 15. stoletje.

Ključne besede: fragmenti, gotske poslikave, zahodni panonski rob, Luksemburžani, visokogotski linearni stil, mešani slog, prehodni slog, mednarodni slog

\author{
Janez Balažic \\ Fragmentarily Preserved Gothic Murals \\ on the Western Edge of Pannonia \\ 1.01 Original scientific article
}

The author discusses the fragmentarily preserved murals attributed to regional painting workshops which exemplify the so-called vertical influence axis on the western edge of Pannonia. Despite their fragmentary condition, the examples discussed make an important contribution to our understanding of the artistic production in this territory at the time of the House of Luxembourg. The paper explores the productive connections between artistic workshops and their patrons. The artistic output of the workshops was characterized by the gradual fading of the high Gothic linear style already before the middle of the $14^{\text {th }}$ Century, and by a 'mixed' or 'transitional' style under Italian Trecento influences in the second half of the $14^{\text {th }}$ Century, whereas at the time of the peak of Czech and Viennese production around 1400 the international Gothic style prevails and is still discernible well into the $15^{\text {th }}$ Century.

Keywords: fragments, Gothic paintings, western edge of Pannonia, the House of Luxembourg, High Gothic linear style, mixed style, transitional style, international style 


\author{
Martina Malešič \\ Risbe iz stockholmskih arhivov. \\ Poskus rekonstrukcije švedske izkušnje arhitektov \\ Franceta in Marte Ivanšek
}

\title{
1.01 Izvirni znanstveni članek
}

Arhitekta France in Marta Ivanšek se v slovenski arhitekturni zgodovini pogosto omenjata kot »ambasadorja« švedske kulture, ki sta iz Skandinavije v slovenski prostor prinesla vrsto za napredek stanovanjskega standarda ključnih modelov, na primer urbanistično idejo nizko-goste stanovanjske zazidave (naselje Murgle v Ljubljani), skandinavski sistem moderne laboratorijske kuhinje (SVEA) ter tečaje Barva in oblika. Švedsko izkušnjo arhitektov Ivanšek omenjajo številni raziskovalci povojne slovenske arhitekture, vendar področje še ni bilo podrobno raziskano in predstavljeno. Prispevek prinaša vpogled $\mathrm{v}$ leta, ki sta jih Ivanška preživela $\mathrm{v}$ Stockholmu. S pomočjo primarnega gradiva iz stockholmskih arhivov, lastnih zapisov arhitektov in korespondence poskuša rekonstruirati njuno bivanje in delo v Stockholmu.

Ključne besede: France Ivanšek, Marta Ivanšek, stanovanjska gradnja, Švedska, bivanjska kultura, slovenska arhitektura

\section{Mateja Maučec \\ Vizualna propaganda Stadlerjevih ekumenskih prizade- vanj $v$ freskah Ivane Kobilce}

\subsection{Izvirni znanstveni članek}

Članek se ukvarja z likovnim prispevkom slovenske slikarke Ivane Kobilce v sarajevski semeniški cerkvi sv. Cirila in Metoda. Poslikava dela cerkve je bila med prvimi naročili, ki jih je umetnica pridobila v Sarajevu, ter po obsegu tudi njeno največje delo. Umetnica je poslikala del kupole, severni steni obeh krakov transepta in štiri tonde, dva na pevskem koru ter dva na stranskih emporah. Za freske, ki združujejo jezuitsko in ekumensko ikonografijo, je ikonografski program sestavil prvi sarajevski nadškof dr. Josip Stadler, freske pa so priča njegovih neuresničenih cerkveno-političnih ambicij po združitvi vzhodne in zahodne Cerkve.

Ključne besede: ekumenizem, Josip Stadler, stensko slikarstvo, Ivana Kobilca, vizualna propaganda, Bosna in Hercegovina

\author{
Martina Malešič \\ Drawings from the Stockholm Archives. \\ An Attempt to Reconstruct the Swedish Experience \\ of Architects France and Marta Ivanšek
}

1.01 Original scientific article

Slovene architectural history often mentions the architects France and Marta Ivanšek as 'ambassadors' of Swedish culture. From Scandinavia they brought a number of models which proved to be crucial for the improvement of housing standards such as the idea of low-rise high-density housing (e.g. the Murgle development in Ljubljana), Scandinavian modern kitchen design (SVEA) and the Barva in Oblika ('Colour and Form') courses on the Swedish Natural Colour System and its applicatibility in design, architecture and textile industry. Numerous researchers of post-war Slovenian architecture have mentioned France and Marta Ivanšek's Swedish experience, but the topic has not yet been researched or presented in detail. This article seeks to provide an insight into the years the architects spent in Stockholm. Based on primary sources from the Stockholm archives, the architects' own records and correspondence, it reconstructs their stay and work in Stockholm.

Keywords: France Ivanšek, Marta Ivanšek, housing, Sweden, dwelling culture, Slovene architecture

\author{
Mateja Maučec \\ Visual Propaganda of Stadler's Ecumenic Project \\ in Frescoes by Ivana Kobilca
}

\subsection{Original scientific article}

The article deals with the artistic contribution of the Slovene painter Ivana Kobilca in the Sarajevo seminary Church of Sts Cyril and Methodius. The painting of part of the church was among the first commissions that the artist obtained in Sarajevo, and in terms of the scope also her largest work. The artist painted part of the dome, the northern walls of the transept and four tondi, two on the organ loft and two on the side galleries. The iconographic program for the frescoes, which combine Jesuit and ecumenical iconography, was designed by the first archbishop of Sarajevo, Dr. Josip Stadler. The frescoes attest to his unrealized ecclesiastical and political ambitions of unifying the Eastern and Western Churches.

Keywords: ecumenism, Josip Stadler, wall painting, Ivana Kobilca, visual propaganda, Bosnia and Herzegovina 


\author{
Mija Oter Gorenčič \\ Redovne in umetnostne povezave med Gamingom in \\ kartuzijami $v$ današnji Sloveniji s posebnim ozirom na \\ memorio in likovno reprezentacijo Habsburžanov in \\ grofov Celjskih
}

1.01 Izvirni znanstveni članek

V članku so predstavljene redovne in umetnostne povezave kartuzij na Slovenskem s kartuzijo Gaming. Raziskava je pokazala, da je do okrog leta 1500 potekala relativno pogosta izmenjava priorjev in menihov med Gamingom in slovenskimi kartuzijami. V večini primerov je šlo za prihode menihov iz Gaminga v slovenske kartuzije, redkejši pa so bili odhodi iz slovenskih kartuzij v Gaming. Tudi umetnostnozgodovinska primerjalna in slogovna analiza sta razkrili več doslej še neopaženih povezav. Povezavo razkrivajo tudi posamezni ujemajoči se kamnoseški znaki. V slovenskih kartuzijah izstopa umetnostno naročništvo grofov Celjskih. Ti bi se pri likovni reprezentaciji lahko zgledovali prav po načinih, ki so se jih z namenom memorie v Gamingu posluževali Habsburžani.

Ključne besede: kartuzijani, kartuzijanska arhitektura, srednji vek, grofje Celjski, Habsburžani, Gaming, Žiče, Jurklošer, Bistra, Pleterje, memoria, likovna reprezentacija

\section{Vaidas Petrulis \\ Kaunas - baltsko vrtno mesto?}

\subsection{Izvirni znanstveni članek}

Med letoma 1919 in 1939, ko je imel Kaunas status začasne prestolnice Litve, sta krojila arhitekturni značaj njegovega urbanega okolja procesa, ključna za tisti čas modernizacija in napredek. V dvajsetih letih 20. stoletja je v hitro rastoči prestolnici vladalo veliko pomanjkanje stanovanj, zato so bile stanovanjske stavbe pomemben del gradbene dejavnosti in mestnega programa modernizacije skozi celotno medvojno obdobje. Med dokumente, ki so vplivali na koncept bivalnega okolja, spada urbanistični načrt za Kaunas, ki sta ga leta 1923 zasnovala danski inženir in urbanist Marius Frandsen in litovski arhitekt Antanas Jokimas. Projekt je predvidel razdelitev mesta na različne funkcionalne cone. Eno teh območij - rezidenčni Žaliakalnis - priča, da so bile med najpomembnejšimi urbanističnimi pobudami v ozadju projekta eksperimentalne zamisli Ebenezerja Howarda o vrtnem mestu. Članek s pomočjo zgodovinskih virov

\section{Mija Oter Gorenčič}

Monastic and Artistic Connections between Gaming and the Charterhouses in Present-Day Slovenia with Particular Regard to Memoria and the Visual

Representation of the Habsburgs and the Counts of Cilli

\subsection{Original scientific article}

The article presents the monastic and artistic connections between the charterhouses in Slovenia and the Gaming Charterhouse. The research shows that until around 1500 there was a relatively frequent exchange of priors and monks between Gaming and Slovenian charterhouses. In most cases these exchanges related to monks from Gaming coming to Slovenian charterhouses, while departures from Slovenian charterhouses to Gaming were considerably less frequent. Comparative and stylistic art historical analyses reveal several previously unnoticed connections. The matching mason's marks also attest to this connection. The artistic patronage of the Counts of Cilli stands out in the Slovenian charterhouses. In the visual representation they could have imitated the artistic ways used by the Habsburgs for their memoria in Gaming.

Keywords: Carthusians, Carthusian architecture, Middle Ages, Counts of Cilli, House of Habsburg, Gaming, Seitz, Gairach, Freudenthal, Pletriach, memoria, visual representation

\section{Vaidas Petrulis \\ Kaunas - a Baltic Garden City?}

\subsection{Original scientific article}

From 1919 to 1939, when Kaunas assumed the status of the provisional capital of Lithuania, the architectural character of its urban environment was forged by the processes that were characteristic of that period - modernization and progress. In the 1920s housing was in severely short supply in the rapidly growing capital, so residential buildings were a significant part of construction activity and of the city's modernization programme throughout the interwar period. Among the documents influencing the concept of living environment was a new master plan for Kaunas developed in 1923 by Danish engineer and urban planner Marius Frandsen and Lithuanian architect Antanas Jokimas. The project proposed dividing the city into different functional zones. One of these areas, residential Žaliakalnis, testifies to the fact that the experimental thoughts of Ebenezer Howard's garden city were among the most important 
preučuje, kako so Litovci poskušali posvojiti to idejo. S primerjavo teoretičnih prizadevanj in praktičnih aplikacij eksperimenta vrtnega mesta članek dokazuje, da spada Kaunas med mesta, v katerih je univerzalni koncept zelenih predmestij našel plodna tla.

Ključne besede: vrtno mesto, zeleno predmestje, modernizem, medvojna Evropa, Litva

\author{
Damjan Prelovšek \\ Plečnikovi načrti za cerkev sv. Križa v Zagrebu
}

\subsection{Izvirni znanstveni članek}

Arhitekt Jože Plečnik je za zagrebške frančiškane iz province sv. Cirila in Metoda naredil več predlogov cerkve sv. Križa s samostanom, ki naj bi postala središče nove župnije istega imena. Prvotni prostor je bil Trg kralja Petra Krešimirja. Ker pa regulacija tega dela mesta še ni bila določena, je moral svoje načrte spremeniti. Gradnjo je preprečil začetek druge svetovne vojne, po njej pa je Plečnik svoj projekt dolge in ozke cerkve (1939) zamenjal s centralno stavbo (1946-1947), ki povzema zamisli njegove neuresničene sarajevske katedrale sv. Jožefa in sočasnega načrtovanja stavbe slovenskega parlamenta. Intenzivno ukvarjanje s tem naročilom označuje širok razpon tipoloških in ustvarjalnih možnosti.

Ključne besede: Jože Plečnik, Dioniz Andrašec, zagrebški frančiškani, župnija sv. Križa, sakralna arhitektura, jezuitski samostan v Osijeku, slovenski parlament

\author{
Alessandro Quinzi \\ Rodbinske ambicije Sigismunda grofa \\ Attems Petzenstein v luči umetnostnih naročil \\ 1.01 Izvirni znanstveni članek
}

Sigismund grof Attems Petzenstein (1708-1758) je sredi 18. stoletja svojo rodbino "povzdignil do take veličine, kakršne ni dosegla v vseh preteklih časih« (G. Guelmi, urban inspirations behind it. Through the lens of the historical sources, the article examines how Lithuanians attempted to adopt this idea. Comparing the theoretical aspirations and the practical applications of the garden city experiment, the article argues that Kaunas is among the cities where the universal concept of green suburbs found fertile ground.

Keywords: garden city, green suburbs, modernism, interwar Europe, Lithuania

\section{Damjan Prelovšek}

Plečnik's Plans for the Church of the Holy Cross in Zagreb

\subsection{Original scientific article}

Architect Jože Plečnik prepared several proposals for the church of the Holy Cross and the monastery for the Zagreb Franciscans from the province of Sts Cyril and Methodius, which was to become the centre of the new parish with the same name. The original location for the project was the Square of King Peter Krešimir. However, since the traffic regulation for this part of town had not yet been determined, he had to change his plans. The construction was prevented by the start of World War II, and after it, Plečnik replaced his design for a long and narrow church (1939) with a central building (19461947), which summarises his ideas for the unrealized cathedral of St Joseph in Sarajevo and the concurrent work on the National Assembly Building of Slovenia. The intensive work on this commission is characterized by a wide range of typological and creative possibilities.

Keywords: architect Jože Plečnik, Dioniz Andrašec, the Zagreb Franciscans, parish of the Holy Cross, religious architecture, Jesuit monastery in Osijek, National Assembly Building of Slovenia

\author{
Alessandro Quinzi \\ The Family Ambitions of Sigismund Attems \\ Petzenstein in the Light of his Art Commissions \\ 1.01 Original scientific article
}

In the mid- $18^{\text {th }}$ Century Count Sigismund Attems Petzenstein (1708-1758) "raised his family to such greatness as it had not attained in all past times" (G. Guelmi, Storia 
Storia genealogico-cronologica degli Attems austriaci, 1783). Na novo pridobljeni ugled je pospremil s postavitvijo mestne rezidence na Kornu (1745) in vile v Podgori (1747-1748) ter $\mathrm{z}$ obnovo dvorca na Jazbinah (1747). Leta 1750 , ob imenovanju brata Karla Mihaela (1711-1774) za prvega goriškega nadškofa, pa je dal modernizirati pročelje mestne palače. $\mathrm{Za}$ gradbene podvige je Sigismund praviloma zaposlil arhitekta Saveria Giannija, kar dokazujejo prvič objavljeni podatki iz zapuščinskega inventarja. Slikarsko opremo je naročal pri goriških slikarjih (Johann Michael Lichtenreit, Antonio Paroli), le za oltarno sliko družinske kapele v nekdanji cerkvi sv. Frančiška se je obrnil na veronskega umetnika Giambettina Cignarolija. Čeprav Sigismund ni dočakal namestitve slike, se je ravno s tem umetniškim podvigom vpisal v elitni krog evropskih naročnikov Cignarolijevih del.

Ključne besede: Sigismund Attems Petzenstein, Karel Mihael Attems Petzenstein, Saverio Gianni, Giambettino Cignaroli, Gorica, baročna umetnost, arhitektura, 18. stoletje

\section{Samo Štefanac \\ Ponovno o koprski Pietà}

1.01 Izvirni znanstveni članek

Leseni kip Pietà v koprski stolnici, ki je bil leta 2016 v vandalskem napadu poškodovan, je bil podrobneje obravnavan že leta 2005 in pogojno označen kot beneško delo iz sredine 15 . stoletja pod vplivom muranske slikarske šole. Novejše odkritje kaže, da gre po vsej verjetnosti za padovansko delo, prav tako iz sredine 15 . stoletja. Doslej namreč ni bil opažen približno sočasni kip Pietà v Piove di Sacco, ki je nedvomno delo iste roke kot koprski in ga lahko povežemo s slikarstvom Squarcionejevega kroga.

Ključne besede: Pietà, kiparstvo 15. stoletja, Koper/Capodistria, Piove di Sacco, Padova genealogico-cronologica degli Attems austriaci, 1783). He cemented the newly acquired reputation with the erection of a town residence in Corno Square (1745), a villa in Podgora (Piedimonte, 1747-1748) and the renovation of the mansion at Jazbine (Giasbana, 1747), all in Gorizia. In 1750, when his brother Karl Michael (1711-1774) was appointed the first archbishop of Gorizia, he had the façade of the town palace modernized. As a rule, Sigismund used the architect Saverio Gianni to execute the works, as is evidenced by data from the estate inventory now published for the first time. He commissioned paintings from the Gorizian painters Johann Michael Lichtenreit and Antonio Paroli, whereas for the altar painting of the family chapel in the former church of St Francis he turned to the Veronese artist Giambettino Cignaroli. Although Sigismund did not live to see the painting hung, it was by means of this artistic commission that he joined the elite circle of Cignaroli's European clients.

Keywords: Sigismund Attems Petzenstein, Karl Michael Attems Petzenstein, Saverio Gianni, Giambettino Cignaroli, Gorizia, Baroque art, architecture, $18^{\text {th }}$ Century

\section{Samo Štefanac \\ The Koper Pietà Revisited \\ 1.01 Original scientific article}

The wooden Pietà sculpture in the Koper Cathedral, which was damaged in a vandal attack in 2016, was studied in considerable detail in 2005 and was provisionally labelled as a Venetian work from the middle of the $15^{\text {th }}$ Century influenced by the Murano painting school. The latest findings show that the work most probably originates from Padua, also from the middle of the century. The roughly contemporary sculpture of Pietà in Piove di Sacco, which was undoubtedly made by the same sculptor as the Pietà in Koper and can be related to the painting of the circle of Francesco Squarcione, had not been noticed until now.

Keywords: Pietà, $15^{\text {th }}$ Century sculpture, Koper/Capodistria, Piove di Sacco, Padua 


\section{Polona Vidmar}

Prednik ali kralj? Recepcija portretov iz 17. stoletja

$v$ času Franca Jožefa kneza Dietrichsteina (1767-1854)

\subsection{Izvirni znanstveni članek}

Prispevek osvetljuje zanimanje Franca Jožefa kneza Dietrichsteina za zgodovino njegove rodbine, ki se je med drugim odrazilo v nakupu izvornega rodbinskega sedeža Dietrichstein na Koroškem leta 1838. Na podlagi še neobjavljene knezove korespondence $\mathrm{z}$ uradniki gospostev Dietrichstein in Gornji Ptuj, ki ju je rodbina podedovala po grofih Lesliejih, je analizirano njegovo iskanje sledi za predniki na Koroškem in Štajerskem, prikazani pa so tudi nakupi predmetov. Predstavljene so knezove težnje, da bi s podedovanimi, kupljenimi in naročenimi portreti poudaril pomen svoje rodbine in prednikov. Kot vzorčni primer recepcije portretov je izbrana serija štirinajstih portretov evropskih vladarjev, ki jo je Jakob grof Leslie v letih od 1669 do 1673 naročil za opremo dvorane ptujskega gradu. V inventarjih gradu Gornji Ptuj so od leta 1835 sedem portretirancev in portretirank kljub nedvoumnim rekvizitom, kot so krone, vladarska jabolka in žezla ter kronanjski plašči, prepoznavali kot člane in članice rodbine Leslie. Upodobljence je ustrezneje identificiral direktor knežje galerije Franz Kutschera leta 1857, tik preden so jih leta 1860 odpeljali na Dunaj in od tam v grad Frýdlant na Češkem. Prispevek osvetljuje tudi pomen knežjih uradnikov, zlasti Moritza Seehanna in Ferdinanda Raispa, za razcvet zanimanja za zgodovino in umetnostne spomenike na Ptuju v 19. stoletju.

Ključne besede: portret, baročno slikarstvo, naročništvo, transfer umetnin, ptujski grad, Franc Jožef knez Dietrichstein, Jakob grof Leslie, Ferdinand Raisp

\section{Polona Vidmar}

Ancestor or King? The Reception of $17^{\text {th }}$ Century

Portraits in the Time of Franz Joseph,

Prince of Dietrichstein (1767-1854)

\subsection{Original scientific article}

The article seeks to shed light on Franz Joseph, Prince of Dietrichstein's interest in the history of his own family, which was reflected among other things in his purchase of the original Dietrichstein family seat in Carinthia in 1838. Franz Joseph's search for the traces of his ancestors in Carinthia and Styria as well as his purchases of objects are analysed based on the prince's not yet published correspondence with the clerks of the seigneuries of Dietrichstein and Gornji Ptuj, which his family inherited from the Counts of Leslie. The article discusses the prince's aspirations to use the inherited, purchased, and commissioned portraits to emphasise the significance of his family and ancestors. As a representative example of the reception of portraits, a series of 14 portraits of European rulers, which Jakob Count of Leslie commissioned for the furnishing of the hall of Ptuj castle between 1669 and 1673 was chosen. Since 1835, seven of the 'sitters' had been recognized in the inventories of the Gornji Ptuj castle as members of the Leslie family, despite the presence of unambiguous props in the paintings, such as crowns, royal orbs and sceptres, and coronation cloaks. The individuals depicted were more accurately identified by the director of the princely gallery Franz Kutschera in 1857, shortly before they were taken to Vienna in 1860 , and from there to Frýdlant castle in Bohemia. The paper also highlights the significance of the princely clerks, especially Moritz Seehann and Ferdinand Raisp, for the burgeoning interest in historical and artistic monuments in Ptuj in the $19^{\text {th }}$ century.

Keywords: portrait, Baroque painting, patronage, transfer of artworks, Ptuj castle, Franz Joseph Prince of Dietrichstein, Jakob Count of Leslie, Ferdinand Raisp 


\section{SodelaVcI}

\section{CONTRIBUTORS}

Doc. dr. Janez Balažic

Univerza v Mariboru, Pedagoška fakulteta

Oddelek za likovno umetnost

Koroška cesta 160

SI-2000 Maribor

janez.balazic@um.si

Asist. dr. Martina Malešič

Univerza v Ljubljani, Filozofska fakulteta

Oddelek za umetnostno zgodovino

Aškerčeva 2

SI-1000 Ljubljana

martina.malesic@ff.uni-lj.si

Mateja Maučec

Bratov Učakar 118

SI-1000 Ljubljana

mateja.maucec@gmail.com

Doc. dr. Mija Oter Gorenčič

ZRC SAZU, Umetnostnozgodovinski inštitut

Franceta Steleta

Novi $\operatorname{trg} 2$

SI-1000 Ljubljana

mija.oter@zrc-sazu.si

Dr. Vaidas Petrulis

Kauno technologijos universitetas, Architektūros

ir statybos institutas

Architektūros ir urbanistikos tyrimų centras

Tunelio gatvè 60

LT-44405 Kaunas

Lietuva

vaidas.petrulis@ktu.lt
Dr. Damjan Prelovšek

Zarnikova ulica 11

SI-1000 Ljubljana

damjan.prelovsek@zrc-sazu.si

Alessandro Quinzi
Musei Provinciali di Gorizia
Borgo Castello 13
IT-34170 Gorica
alessandro.quinzi@provincia.gorizia.it

Red. prof. dr. Samo Štefanac

Univerza v Ljubljani, Filozofska fakulteta

Oddelek za umetnostno zgodovino

Aškerčeva 2

SI-1000 Ljubljana

samo.stefanac@ff.uni-lj.si

Izr. prof. dr. Polona Vidmar

Univerza v Maribori, Filozofska fakulteta

Koroška cesta 160

SI-2000 Maribor

polona.vidmar@um.si 


\section{VIRI ILUSTRACIJ \\ Photographic Credits}

Janez Balažic

1-2, 6-15, I-VI: Janez Balažic.

3: (C) Nagyboldogasszony (Bencés) Templom, Šopron.

4-5 : ( O Országos Müelmlékvédelmi Hivatal, Budimpešta.

\section{Martina Malešič}

1-2, 6-7, 9, 11, 14-15: (C) Ustanova France in Marta Ivanšek, Ljubljana.

3-5, 8, 10, 12-13: (C) Svenskt arkitektur- och designcentrum ArkDes, Stockholm.

\section{Mateja Maučec}

1: Arhiv Republike Slovenije, Ljubljana.

2-6: Mateja Maučec.

7-8: D. Damjanović, Umjetnićko blago Strossmayerove katedrale u Đakovu, Đakovo 2017.

\section{Mija Oter Gorenčič}

1: (C) INDOK center, Direktorat za kulturno dediščino, Ministrstvo za kulturo Republike Slovenije, Ljubljana (risala: Zvonimir Juretin 1971 (zgoraj), A. Koštomaj 1964 (spodaj)).

2-4, 8: (C ZRC SAZU, Umetnostnozgodovinski inštitut Franceta Steleta, Ljubljana (foto: Mija Oter Gorenčič).

5, 9: (C) ZRC SAZU, Umetnostnozgodovinski inštitut Franceta Steleta, Ljubljana (risal: Nejc Bernik). 6: Maisons de l'Ordre des Chartreux. Vues et notices, 4, Parkminster 1919.

7: (C) ZRC SAZU, Umetnostnozgodovinski inštitut Franceta Steleta, Ljubljana (foto: Andrej Furlan). 10-13: (C) ZRC SAZU, Umetnostnozgodovinski inštitut Franceta Steleta, Ljubljana (foto: Gorazd Bence). 14: osebni arhiv avtorice.

\section{Vaidas Petrulis}

1, 13: (C) Kauno regioninis valstybės archyvas, Kaunas.

2: Personal collection of Antanas Burkus.

3-4: Kauno miesto statistikos metraštis, 1, Kaunas 1939.

5, 9-11: (C) Lietuvos centrinis valstybės archyvas, Vilnius.

6: (c) Lietuvos nacionalinis muziejus, Vilnius.

7: Statybos menas ir technika, 1/2-3, 1922.

8: Vaidas Petrulis.

12: Edward Denison.

14-15: (C Šiaulių „Aušros“ muziejus, Šilauliai (foto: Vincas Uždavinys).

\section{Damjan Prelovšek}

1: F. Stele, A. Trstenjak, J. Plečnik, Architectura perennis, Ljubljana 1941.

2 -5, 7-13: (C) Muzej in galerije mesta Ljubljana.

6: (C) Arhiv province sv. Cirila in Metoda, Zagreb (foto: Damjan Prelovšek). 


\section{Alessandro Quinzi}

1: (C) Narodna galerija, Ljubljana.

2-7: (C) Musei Provinciali di Gorizia, Gorica (foto: Carlo Sclauzero).

\section{Samo Štefanac}

1, 4-6, 12, 14: Samo Štefanac.

2: Dioecesis Iustinopolitana. Spomeniki gotske umetnosti na območju koprske škofije, Koper 2000.

3: Matej Klemenčič.

7-11, 13: () Diocesi di Padova.

\section{Polona Vidmar}

1, 3-4: ( ) Moravský zemský archiv v Brně, Brno (foto: Polona Vidmar).

2, 6, 8: ( Knjižnica Ivana Potrča, Ptuj.

5: Barbara Žabota.

7: (C) Státní oblastní archiv v Zámrsku, Zámrsk (foto: Polona Vidmar).

9: (C) Pokrajinski muzej Ptuj - Ormož, Ptuj, fototeka.

10: () Zgodovinski arhiv Ptuj (foto: Branko Vnuk).

11-13, 15-18: (C) Státní hrad a zámek Frýdlant, Frýdlant.

14: Vnderschidliche geistliche vnd weltliche, weibliche, vnd mannliche Contrafait /.../, Ljubljana-Zagreb 2008.

19: (C) Státní hrad a zámek Frýdlant, Frýdlant (foto: Polona Vidmar). 


\section{(C) 2021, avtorji in ZRC SAZU}

Besedilo tega dela je na voljo pod pogoji slovenske licence Creative Commons 4.0 CC BY NC ND, ki pa ne velja za slikovno gradivo. Za kakršnokoli nadaljnjo rabo slikovnega gradiva je treba pridobiti dovoljenje imetnika avtorskih pravic, navedenega $\mathrm{v}$ poglavju Viri ilustracij. Za avtorske pravice reprodukcij odgovarjajo avtorji objavljenih prispevkov.

\section{(C) 2021, Authors and ZRC SAZU}

The text of this publication is available under the conditions of the Slovenian licence Creative Commons 4.0 CC BY NC ND, which is not valid for the published images. Any further use of images requires permission from the copyright holder, stated in the section Photographic Credits. The copyrights for reproductions are the responsibility of the authors of published papers. 
ACTA HISTORIAE ARTIS SLOVENICA 26|1 • 2021

\section{Vsebina $\cdot$ Contents}

Janez Balažic, Fragmentarno ohranjene gotske stenske poslikave na zahodnem panonskem robu • Fragmentarily Preserved Gothic Murals on the Western Edge of Pannonia

Mija Oter Gorenčič, Die monastischen und kunsthistorischen Beziehungen zwischen Gaming und den Kartausen im heutigen Slowenien unter besonderer Berücksichtigung der Memoria und der Herrschaftsrepräsentation der Habsburger und der Grafen von Cilli • Redovne in umetnostne povezave med Gamingom in kartuzijami v današnji Sloveniji s posebnim ozirom na memorio in likovno reprezentacijo Habsburžanov in grofov Celjskih

Samo Štefanac, Ponovno o koprski Pietà • Di nuovo sulla Pietà di Capodistria

Alessandro Quinzi, Rodbinske ambicije Sigismunda grofa Attems Petzenstein v luči umetnostnih naročil •

Le ambizioni familiari del conte Sigismondo Attems Petzenstein alla luce delle committenze artistiche

Polona Vidmar, Vorfahr oder König? Zur Rezeption der Porträts des 17. Jahrhunderts unter Franz Josef Fürst Dietrichstein (1767-1854) • Prednik ali kralj? Recepcija portretov iz 17. stoletja v času Franca Jožefa kneza Dietrichsteina (1767-1854)

Mateja Maučec, Vizualna propaganda Stadlerjevih ekumenskih prizadevanj v freskah Ivane Kobilce • visual Propaganda of Stadler's Ecumenic Project in Frescoes by Ivana Kobilca

Vaidas Petrulis, Kaunas - a Baltic Garden City? • Kaunas - baltsko vrtno mesto?

Damjan Prelovšek, Plečnikovi načrti za cerkev sv. Križa v Zagrebu • Plečnik's Plans for the Church of the Holy Cross in Zagreb

Martina Malešič, Risbe iz stockholmskih arhivov. Poskus rekonstrukcije švedske izkušnje arhitektov Franceta in Marte Ivanšek - Drawings from the Stockholm Archives. An Attempt to Reconstruct the Swedish Experience of Architects France and Marta Ivanšek

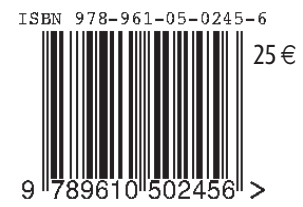

